Louisiana State University

LSU Digital Commons

1969

\title{
Influence of Aldosterone on the Quality of Porcine Muscle.
}

Ferdinand Ludvic Passbach Jr

Louisiana State University and Agricultural \& Mechanical College

Follow this and additional works at: https://digitalcommons.Isu.edu/gradschool_disstheses

\section{Recommended Citation}

Passbach, Ferdinand Ludvic Jr, "Influence of Aldosterone on the Quality of Porcine Muscle." (1969). LSU Historical Dissertations and Theses. 1682.

https://digitalcommons.Isu.edu/gradschool_disstheses/1682

This Dissertation is brought to you for free and open access by the Graduate School at LSU Digital Commons. It has been accepted for inclusion in LSU Historical Dissertations and Theses by an authorized administrator of LSU Digital Commons. For more information, please contact gradetd@lsu.edu. 
This dissertation has been

microfilmed exactly as received

$70-9082$

PASSBACH, Jr., Ferdinand Ludvic, 1941INFLUENCE OF ALDOSTERONE ON THE QUALITY OF PORCINE MUSCLE.

The Louisiana State University and Agricultural and Mechanical College, Ph.D., 1969

Chemistry, biological

University Microfilms, Inc., Ann Arbor, Michigan 


\section{INFLUENCE OF ALDOSTERONE ON THE QUALITY OF PORCINE MUSCLE}

\section{A Dissertation}

Submitted to the Graduate Faculty of the Louisiana State University and Agricultural and Mechanical College in partial fulfillment of the requirements for the degree of Doctor of Philosophy

in

The Department of Animal Science

by

Ferdinand Ludvic Passbach, Jr.

B.S., Mississippi State University, 1963

M.S., Mississippi State University, 1965

August, 1969 


\section{ACKNOWLEDGEMENTS}

The author wishes to express sincere appreciation and gratitude to the following persons:

Dr. A. M. Mullins, Major Professor, for his stimulating suggestions, valuable guidance, untiring assistance and amiable affiliation throughout the course of graduate study.

Drs. G. L. Robertson, J. G. Lee, C. K. Vincent, and J. W. Turner for their advice on problems in this study and their constructive criticisms in compiling this manuscript.

Mrs. B. A. Paul for her congenial attitude and never-ending assistance in carrying out the laboratory analyses.

Dr. V. K. Wipf, a colleague, for his suggestions and assistances in all aspects of this study.

Dr. D. M. Thrasher, Mr. C. J. LeBlanc and Mr. W. D. Simoneaux for procuring and caring for the experimental animals.

Mr. Lee P. Bertrand and Mr. Thomas Barnes for their cooperation in the processing of the experimental animals.

Mr. Felipe Diez, Mr. J. W. Rundell, Mr. Daniel Melancon and Mr. Mike Burns for their assistance in the treatment of the experimental animals. 


$$
\text { Dr. K. L. Koonce for his a id in tic stotistical }
$$

analyses.

American ileat Institute Founciation for larial support of this investigation.

And my parents for the encouragement, sacrifice, and unselfish love necessary to make the preparation of this manuscript possible. It is to them that I dedicate this dissertation. 
TABLE OF CONTENTS

Page

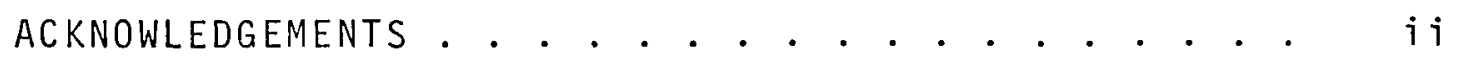

LIST OF TABLES . . . . . . . . . . . . . . . . . . . . vi vi

LIST OF FIGURES . . . . . . . . . . . . . . . . . . $v i \mathrm{i}$

ABSTRACT . . . . . . . . . . . . . . . . . . . . . ${ }^{\circ} \vee i i$

INTRODUCTION . . . . . . . . . . . . . . . . . . . . 1

LITERATURE REVIEW . . . . . . . . . . . . . . . . 3

Pork Muscle Quality . . . . . . . . . . . . . 3

Hormonal Influences on PSE Muscle . . . . . . . . 3

Aldosterone . . . . . . . . . . . . . . . . . 8

Physiological Effects of Aldosterone. . . . . . . 8

Control of Aldosterone Secretion . . . . . . . . 10

Abnormalities of Aldosterone Secretion . . . . . 10

Aldosterone and Stress... . . . . . . . . . 12

Aldosterone Antagonists . . . . . . . . . . . 12

Sodium and Potassium Content of Pork. . . . . . . 13

Pyruvate Kinase . . . . . . . . . . . . . . . 14

MATERIALS AND METHODS . . . . . . . . . . . . . . 18

Treatments.................. . . . . 18

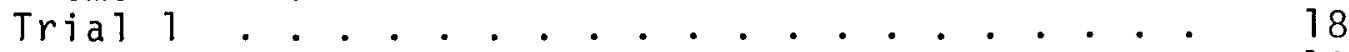

Trial 2 . . . . . . . . . . . . . . . . . 19

Trial 3 . . . . . . . . . . . . . . . . . . . . 19

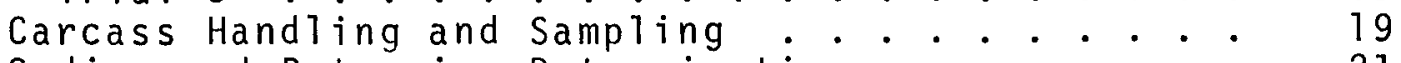

Sodium and Potassium Determination . . . . . . . 21

Serum Preparation . . . . . . . . . . . . . . 21

Muscle Preparation . . . . . . . . . . . . . 21

Water Binding Determination . . . . . . . . . . 22

Protein Turbidity Determination . . . . . . . . . 22

Statistical Analyses................ . 23

Source of Compounds . . . . . . . . . . . . . 24

Pyruvate Kinase Trial . . . . . . . . . . . . 24 
Page

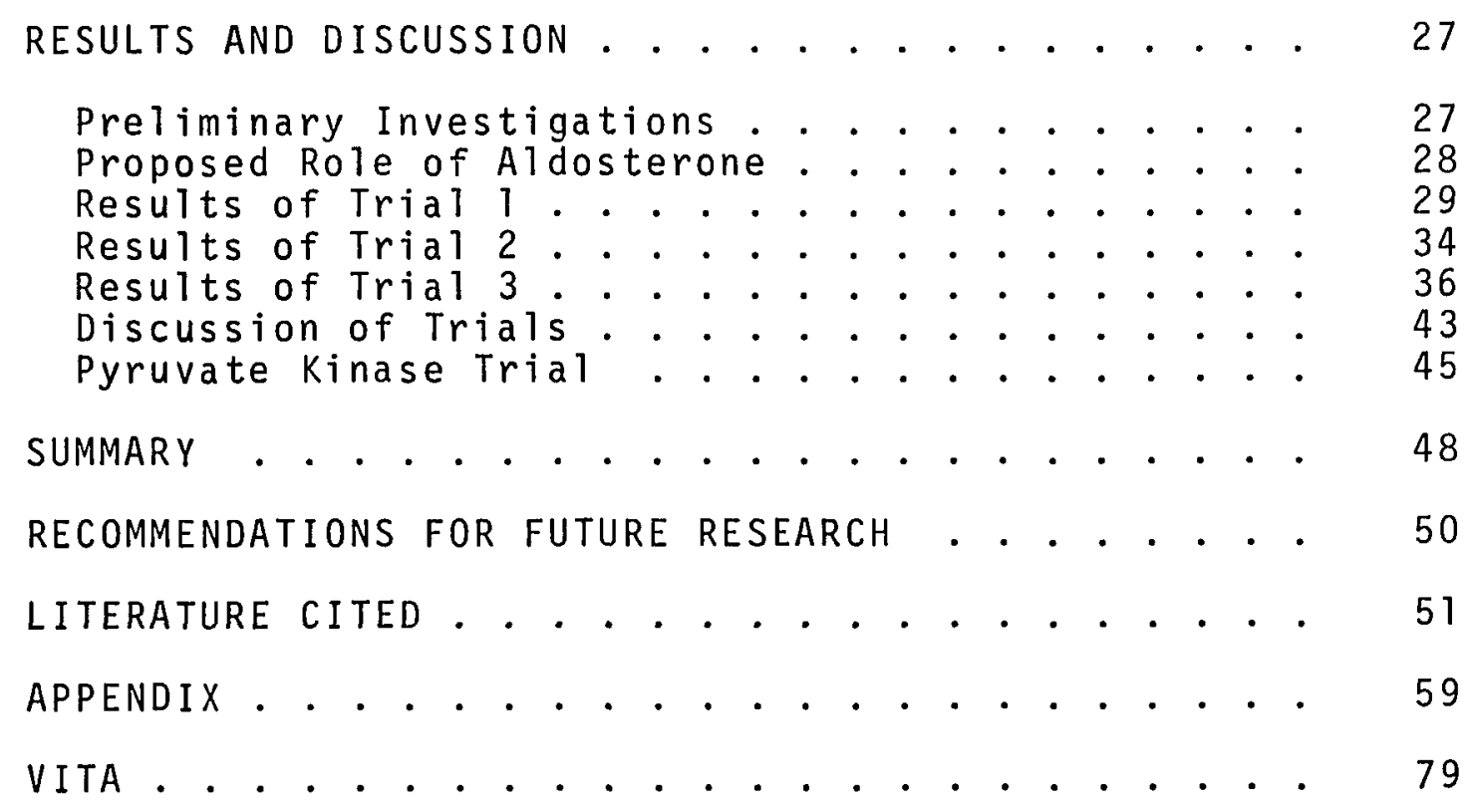




\section{LIST OF TABLES}

Table

Page

1. Means and Standard Errors for Subjective and Objective Quality Evaluations... . . . . 32

2. Means and Standard Errors for Sodium and

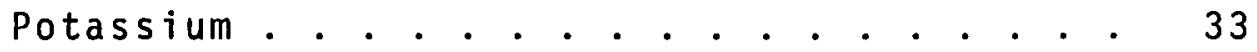

3. Least-Squares Means and Standard Errors for Subjective and Objective Quality Evaluations 37

4. Least-Squares Means and Standard Errors for Sodium and Potassium . . . . . . . . . 38

5. Means and Standard Errors for Subjective and Objective Quality Evaluations....... . . 41

6. Means and Standard Errors for Sodium and Potassium.....................

7. Pyruvate Kinase Activity of Pork Muscle and Liver........... . . . . . . . . 


\section{LIST OF FIGURES}

Figure

Page

1. Ham and Loin of Control for Trial 1 . . . . 30

2. Ham and Loin of Aldosterone Treated for Trial 1................. 30

3. Ham and Loin of Control for Trial 2 . . . . 35

4. Ham and Loin of Aldactone Treated for Trial 2................ 35

5. Ham and Loin of Control for Trial 3..... 39

6. Ham and Loin of Aldactazide Treated for Trial 3................. 39 


\section{ABSTRACT}

The influence of aldosterone and aldosteroneblocking agents on porcine muscle quality, and the possible role of aldosterone in the etiology of pale, soft, exudative (PSE) porcine musculature were studied. Preliminary investigations indicated that an intravenous injection of $1.5 \mathrm{mg}$. of aldosterone, followed by an hour and a half equilibration period, would produce PSE musculature. Also, an oral drench of $500 \mathrm{mg}$. of Aldactazide followed by a 30 min. equilibration period would prevent the development of PSE musculature resulting from a $30 \mathrm{~min}$. stress period with an electric prod.

Thirty-four Poland China pigs, approximately $95 \mathrm{~kg}$, were divided into three trials of 12,10 and 12 pigs each and treated with $1.5 \mathrm{mg}$. aldosterone, $250 \mathrm{mg}$. Aldactone and $500 \mathrm{mg}$. Aldactazide, respectively. The pigs in the latter two trials were stressed for 30 minutes. The animals were slaughtered and serum and muscle (longissimus dorsi) samples were taken for sodium and potassium determinations. After chilling for $24 \mathrm{hrs}$. at $3^{\circ} \mathrm{C}$, the carcasses were cut and subjective quality scores applied by a three-member panel. The 1 . dorsi muscle was sampled again for determinations of objective estimates of quality. 
The injection of $1.5 \mathrm{mg}$. of aldosterone resulted in a highly significant $(P<.01)$ decrease in Wisconsin Pork Quality Score from 2.8 to 1.8. A similar trend of a reduction in quality was obtained for the objective evaluations. Likewise, the oral administration of $500 \mathrm{mg}$. of Aldactazide significantly $(P<.05)$ increased the Wisconsin Pork Quality score from 1.2 to 2.5 , and improved the objective measure of protein turbidity by reducing the percent transmission from 93.8 to 70.5 . The oral administration of 250 $\mathrm{mg}$. of Aldactone tended to improve the objective measures of quality, but not the subjective measures.

No statistically significant differences were obtained for either serum or muscle sodium or potassium values in this study.

It was postulated that a hyperproduction of aldosterone resulted in a depletion of muscle potassium, inactivating pyruvate kinase, causing a rapid accumulation of lactic acid, resulting in the development of PSE muscle. Results obtained did not substantiate the above hypothesis. Four Hampshire pigs, approximately $95 \mathrm{~kg}$., were subjected to treatments similar to those receiving aldosterone and Aldactazide in order to observe differences in pyruvate kinase activity of muscle and liver. Treatments failed to produce quality differences with regard to PSE conditions; therefore, data obtained on enzyme activity were inconclusive toward substantiating a relationship to PSE conditions. 


\section{INTRODUCTION}

The influence of the endocrine system on the physiological and biochemical etiology of porcine muscle quality, particularly pale, soft, exudative (PSE) musculature, is rapidly becoming more evident. It has been suggested that selection for the "meat-type" hog, one with a greater portion of the carcass composed of ham and loin, has altered the hormonal homeostasis to such an extent that these animals cannot cope with even normal "stressors." The apparent failure of these animals to compensate for certain stress conditions has resulted in a reduction of muscle quality through the development of pale, soft, exudative musculature in their carcasses.

Research over the past 15 years shows many factors to be related to the development of PSE muscle. This condition has been shown to vary with breed and amount of muscling, as well as environmental conditions. It appears when there is a rapid drop in $\mathrm{pH}(<5.3)$ post-mortem while the carcass is at a high temperature $\left(>40^{\circ} \mathrm{C}\right)$. This results in a precipitation of the sarcoplasmic proteins onto the myofibrillar proteins; thereby reducing the ability of the muscle to bind water.

It has been observed in this condition that a rapid 
post-mortem glycolytic rate occurred. Therefore, researchers have investigated some of the hormones which have been shown to influence the rate of glycolysis. Particular attention has been given to hormones of the thyroid and adrenal glands. Within the adrenal gland, major emphas is has centered around the glucocorticoids. However, Henry et al. (1958) reported that pigs with PSE musculature had hyperproduction of aldosterone and somatotropin with a concomitant deficiency of adrenocorticotropin and glucocorticoids.

The objectives of this study were to: 1) study the relationship between aldosterone and aldosterone-blocking agents toward PSE musculature, and 2) explore the role or mode of action of aldosterone in the etiology of PSE muscu1 ature. 


\section{LITERATURE REVIEW}

Pork Muscle Quality

The problem of inferior muscle quality resulting from the development of pale, soft, exudative musculature was first reported by Ludvigsen (1954) as "muskeldegeneration." Since that time many workers have studied this condition in an attempt to elucidate the basic cause or causes. Extensive reviews have been published by Briskey (1957, 1963, 1964), Breidenstein (1963), Bray (1966) and Cassens (1966).

Porcine muscles have been found to have extremely variable post-mortem glycolytic rates (Briskey, 1963). Various types of ante-mortem stress immediately prior to slaughter have been shown to affect the post-mortem changes in porcine muscle (Briskey et al., 1959; Sayre et al., 1961, 1963a, b; Kastenschmidt et a1., 1964, 1965). These changes resulted in a rapid accumulation of lactic acid post-mortem while the carcass was at a high temperature, and a subsequent development of the PSE condition (Briskey, 1964; Briskey et al., 1966). Bendall and Wismer-Pedersen (1962) reported that the drop in pH at this temperature caused a precipitation of the sarcoplasmic proteins onto the myofibrillar proteins, thereby reducing the 
water-holding capacity of these muscles. However, Bodwell et al. (1966) reported that even though a loss in fibrillar water-binding capacity occurred as a consequence of a low $\mathrm{pH}$ and high temperature, a characteristic frequently encountered in soft, watery muscle, low fibrillar waterbinding capacity by itself was not the primary causal factor in making pork muscle appear soft and watery.

In an attempt to understand what was responsible for the variability in the post-mortem glycolytic rate of pork muscle, Kastenschmidt et al. (1958) studied the levels of glycolytic intermediates and cofactors in "slow glycolyzing" muscles from Hampshire and Chester White animals and compared them to levels found in "fast-glycolyzing" muscles in Poland China animals. They found the adenine nucleotide levels were the primary regulator factors for phosphorylase, and that phosphorylase was the primary control site of post-mortem glycolysis. However, phosphofructokinase and pyruvate kinase were also involved in controlling postmortem glycolysis. Significant differences in blood lactate or glucose levels were observed among the groups of pigs.

Hormonal Influences on PSE Muscle

It has been shown that development of PSE muscle was associated with various stress conditions prior to slaughter. Since any stress condition interferes with the 
homeostatic state of the animal, and since the animal's hormonal systems tend to maintain homeostasis, PSE research has attempted to better characterize this relationship. Ludvigsen (1954) suggested that, since the PSE condition was more prevalent in pigs of breeds which have had intensive selection for the ability to grow muscle, there had been automatic selection of a high content of growth stimulating hormone (GSH) in the pituitary and thereby a lower content of thyroid stimulating hormone (TSH) and adrenocorticotropic hormone (ACTH).

Limited and conflicting information is available on the effect of the thyroid hormones on PSE pork. Ludvigsen (1954) and Briskey (1963) reported that thiouracil-induced hypothyroidism in pigs resulted in pale, soft, exudative musculature. Judge et al. (1965) observed that pigs with severe PSE musculature had elevated plasma levels of protein bound $\mathrm{I}^{3}{ }^{31}$, indicating that thyroid hormone and thyroid gland status were related to various post-mortem muscle properties. However, Topel and Merkel (1966) using methylthiouracil and tapazole failed to confirm previous findings. These workers obtained only slight PSE musculature in ham muscles of some methylthiouracil-fed pigs, but no PSE condition occurred in those fed tapazole. Topel and Merkel (1966), also noted decrease in adrenal gland weight as a result of these goitrogens, and concluded that it appeared the development of PSE musculature was not associated 
with hypothyroidism per se, but may be the indirect result from the secondary effects of methylthiouracil upon the adrenal gland.

Two classes of hormones are produced by the adrenal gland. Catecholamines are produced by the medulla and steroids are produced by the cortex. In work concerned with the catecholamines, Trautman et al. (1963) showed that the oral administration of adrenalin prevented the development of the PSE condition, marked by reduced glycogen levels, and retarded pH reduction. Radouco-Thomas (1962) reported that combining adrenalin with ascorbic acid protected against the condition. Aberle and Merkel (1968) reported no beneficial effects from intramuscular injections of epinephrine. They attributed the failure to confirm previous findings to an insufficient period of time between injection and slaughter. Topel (1968) suggested a possible interaction between the catecholamines and the glucocorticoids on micro-circulatory integrity as related to PSE muscle. Merkel (1968) implied that insufficiency of the domestic pig's circulatory system affected his ability to respond to releases of adrenal medullary hormones.

Steroids produced by the cortex consist of two groups of structurally similar compounds having different physiological functions. Most of the attention in PSE research has been focused on the glucocorticoids, since these 
hormones influence carbohydrate metabolism. Based on previous finding of muscle degeneration in rabbits (Germuth et al., 1951; Ellis, 1956) and myopathy in dogs (Faludi et al., 1964) following administration of various glucocorticoids, and since low ACTH levels have been implicated in PSE muscle, Topel and Merkel (1967) used prednisolone and methyprednisolone on pigs. They were successful in obtaining adrenal atrophy and lower 17-hydroxycorticosterone levels, but failed to produce PSE musculature. In previous work Topel et al. (1967) reported slightly lower levels of plasma 17-hydroxycorticosterone in pigs with severe PSE musculature. These workers attributed the failure to demonstrate this in the second experiment to the gluconeogenic effects of the glucocorticoids used upon the ultimate extent and rate of post-mortem anaerobic glycolysis.

The mineralocorticoids, which regulate mineral metabolism or electrolyte balance, have received little consideration in the study of PSE muscle. Henry et al. (1958) reported that pigs with PSE musculature had hyperproduction of aldosterone and somatotropin with a concomitant deficiency of adrenocorticotropin and glucocorticoids. However, Topel and Merkel (1966) and Topel et al. (1967), conducting research closely allied but not directiy related to this problem, failed to support the findings of Henry. 


\section{A1dosterone}

Aldosterone was first isolated by Tait et al. (1952) from an amorphous fraction remaining from adrenal cortical extracts after substances possessing potent "glucocorticoid" activity had been removed. Simpson et al. (1953) elucidated the chemical structure, characterizing it as the 13-aldehyde of corticosterone. Voluminous literature has accumulated regarding the biochemistry and physiology of this hormone. Extensive reviews have been made by Laragh and Kel1y (1964) and Ross (1965).

However, in spite of the wealth of information available on aldosterone, there is a paucity of knowledge regarding its influence on electrolyte metabolism in muscle, particularly porcine muscle. Therefore, this review will deal only with those generally accepted concepts which are pertinent to the role of aldosterone in porcine muscle quality.

Physiological Effects of Aldosterone

Aldosterone, produced by the zona glomerulosa of the adrenal cortex, functions in modifying the rate of transport and the distribution of sodium, potassium, and hydrogen ions across cellular membranes. Although it may possibly affect many if not all tissues, its most important function appears to be promotion of sodium retention and potassium elimination by renal tubular cells. 
The extrarenal effects of aldosterone are not well defined and their physiological significance still remains questionable. However, certain experiments suggest that aldosterone may act to support both myocardial and circulatory function and may therefore be useful in treatment of circulatory failure. Ballard et al. (1960) and Tanz (1962) reported a positive inotropic effect of relatively low concentrations of the hormone on myocardial muscle in vitro. Bein and Jacques (1960) and Spink and Vick (1961) found that aldosterone administration protected various animals from endotoxic shock and that it may also potentiate the pressor effects of pressor agents in this type shock. Combination of aldosterone with angiotension was especially effective in this situation. Levy and Richards (1962) investigated the effect of aldosterone on the electrolyte content and the contractile properties of isolated rabbit atrial muscle. The hormone increased sodium and decreased potassium content of this muscle. Higher concentrations of aldosterone proauced a slightly negative inotropic effect, whereas lower concentrations had no effect. However, Woodbury and Koch (195/), working from the bas is that patients with Conn's syndrome (hyperproduction of aldosterone) showed an increased sodium and decreased potassium content in muscle, were unable to demonstrate similar ionic alterations following subcutaneous injections of $20 \mu \mathrm{g}$ of aldosterone into mice. 
Therefore, it appears aldosterone influences tissues other than those of the kidney. However, the exact nature and effect of this influence are obscure.

\section{Control of Aldosterone Secretion}

The exact regulating mechanism of aldosterone secretion is another area in which many questions remain unanswered. Substances at present which are known to influence the rate of secretion include the plasma potassium concentration, corticotrophin ( $A C T H$ ), and angiotension II (Ross, 1965). The latter is associated with the influence of blood pressure on the juxtaglomerular cells and their release of renin. Beck et al. (1957) reported that an increase in growth hormone increased the amount of aldosterone excreted in the urine, but its secretion could hardly constitute the normal mode of control. Mills et al. (1958) increased aldosterone secretion in dogs by obstructing the thoracic inferior vena cava. Vogt (1960) suggested the secretion of aldosterone to be under the influence of the central nervous system.

\section{Abnormalities of Aldosterone Secretion}

Aldosterone abnormalities are generally accompanied by the following: 1) disorders characterized by potassium wastage, 2) conditions in which there is progressive sodium retention and edema, and 3 ) states characterized mainly by arterial hypertension. 
Primary aldosteronism (Conn's syndrome) arises from an oversecretion resulting from adrenal cortex adenoma. It is characterized by hypertension and severe potassium depretion, manifested by hypokalemic alkalosis and expressed by periodic muscular paresis or paralysis and occasional tetany. Sodium is retained within the intracellular compartment and although extracellular volume is expanded and plasma sodium concentrations tend to be high, edema does not occur (Ross, 1965).

Secondary aldosteronism means that adrenal hyperfunction is a consequence of stimulation from sources extraneous to the adrenal cortex. Adrenal adenomas are usually absent, and hypersecretion is bilateral. This type of hyperaldosteronism is associated with edematous states of other major disturbances such as nephrosis, cirrhosis, or heart failure, and is sometimes confused with oversecretion found in certain forms of arterial hypertension.

The role of aldosterone in "essential hypertension" needs further clarification. Elevated amounts of aldosterone have been found in urine of patients with severe benign and malignant "essential hypertension" and it has been suggested that human arterial hypertension could be caused by mild and chronic hyperaldosteronism (Genest et al., 1957). However, the amount of day-to-day variation of aldosterone excretion of individual patients despite fairly constant sodium intake, and the failure to find elevated 
rates of excretion in patients with untreated mild essential hypertension, does not support this view. It is generally agreed, however, that aldosterone excretion may be elevated in severe benign hypertension and in malignant hypertension (Ross, 1965).

\section{Aldosterone and Stress}

Since aldosterone functions to regulate mineral homeostasis, and since stress from whatever source creates unnatural conditions which interfere with homeostasis, Simpson and Tait (1954) suggested that aldosterone may be involved in Selye's "General Adaptation Syndrome." Also, an increase in aldosterone excretion has been reported as a result of emotional stress (Lamson et al., 1956). Ross (1965) reported on various experiments in which aldosterone was used either alone or in combination with pressor substances to improve the survival rate of animals subjected to endotoxic shock.

\section{Aldosterone Antagonists}

Aldosterone antagonists are of two general types: 1) synthetic antagonists and 2) naturally occurring antagonists. Most of the synthetic antagonists are derivatives of the steroidal spirolactones, which block the action of aldosterone through reversible competitive inhibition. The naturally occurring antagonists are progesterone and derivatives, testosterone and derivatives, and 
glucocorticoids. Progesterone functions as a reversible competitive inhibitor, blocking the sites of action of aldosterone. The mechanism whereby testosterone and the glucocorticoids modify the actions of aldosterone are still ambiguous.

Comprehensive reviews of aldosterone antagonists have been compiled by Kagawa (1964) and Ross (1965).

Sodium and Potassium Content of Pork

Numerous researchers (Kulwich et a1., 1958, 1960, 1961 ; Kirton and Pearson, 1963; Kirton et a1., 1963; Lawrie and Pomeroy, 1963; and Gillett et al., 1965) have investigated the variation existing in the sodium and potassium content of pork and its relation to the determination of lean muscle mass by $k^{40}$. These workers found significant differences to exist in the sodium and potassium content among various muscles, and among various breeds. Gillett et al. (1965) reported that Hampshires contained more potassium and.1ess sodium than Yorkshires on a per unit basis. They also reported that when extreme values were compared, differences as high as $34.7 \%$ potassium per kilogram of muscle were found.

Reports of sodium and potassium values in relation to porcine muscle quality are scant and conflicting. Henry et al. (1958) reported a large increase in sodium and a decrease in potassium in PSE muscle. They also reported an 
increase in serum sodium among PSE pigs. Topel and Merkel (1966), using exogenous goitrogens to alter muscle quality, stated that the sodium and potassium levels in the longissimus dorsi muscle were similar and within normal ranges. However, these workers failed to produce quality differences with their treatments. In another experiment to study the relationship of 17-hydroxycorticosteroid levels to pork quality, Topel et al. (1967) found no significant differences in the sodium and potassium content of either muscles or plasma from various quality classifications. However, muscles from the severe PSE group had a higher mean sodium content than the DFD (dark, firm, dry) group. Beecher et al. (1968), studying the light and dark portions of the semitendinosus muscle, found that the level of potassium was similar in both portions, while sodium concentrations were significantly $(P<.01)$ greater in the semitendinosus dark portion than in the light portion. The workers also stated that other workers (Drahota, 1961; Sreter and Woo, 1963; Swift and Berman, 1959) had observed higher concentrations of potassium and lower concentrations of sodium in white than in red muscle.

\section{Pyruvate Kinase}

A review of literature concerning pyruvate kinase is pertinent because of its role in glycolysis and its potassium dependency. 
A review by Boyer (1962) reported that pyruvate kinase was widely distributed and appeared to be a constituent of all living cells. Studies have been reported which show the presence of the enzyme in nineteen different tissues from eleven animal species ranging from protozoa to mammals and from erythrocytes of six species, as well as yeast, molds, and the seeds or tissues of eight plants.

This enzyme catalyzes the following reaction:

phosphoenolpyruvate (PEP) + adenosine diphosphate (ADP) $\rightleftharpoons$ pyruvate + adenosine triphosphate (ATP).

Under normal conditions, this reaction is considered to be essentially irreversible, thereby acting as a rate controlling step in glycolysis.

However, the role of pyruvate kinase in glucose synthesis is also feasible. Lardy and Ziegler (1945) first demonstrated that pyruvate kinase catalyzed a significant formation of phosphoenolpyruvate from ATP and pyruvate. krimsky (1959) confirmed this finding. Additional support to the reversibility of this reaction was indicated by observations of Von Korff and Twedt (1957) that in the presence of mitochondria carrying out oxidative phosphorylation, a ratio of phosphoenolpyruvate to pyruvate of 10 to 1 was maintained. McQuate and Utter (1959) stated that although the equilibrium of the reaction lies far to the right, the maximum initial velocity of the forward reaction has been reported as only 150 to 200 times that of the back reaction. 
The dependency of pyruvate kinase activity upon univalent cations such as $\mathrm{K}^{+}, \mathrm{Rb}^{+}, \mathrm{NH}_{4}^{+}$or $\mathrm{Cs}^{+}$, divalent cations such as $\mathrm{Mg}^{+2}$ or $\mathrm{Mn}^{+2}$, and the non-activating or inhibitory influence of $\mathrm{Na}^{+}, \mathrm{Li}^{+}$and $\mathrm{Ca}^{+2}$ have been demonstrated by several workers (Kachmar and Boyer, 1953; Suelter et al., 1966; Mildvan and Cohn, 1965; Mildvan and Cohn, 1966). Therefore, the presence or absence of potassium in a biological system could act as a controlling factor on glycolysis or gluconeogenesis.

The influence of certain hormones on pyruvate $\mathrm{ki}-$ nase activity has received minor attention. Weber et al. (1965) reported that enzyme activity decreased to $18 \%$ of the normal value in liver cells of diabetic rats. Treatment with insulin increased activity to $424 \%$ of the value observed in untreated diabetics. They also reported that hepatic pyruvate kinase activity was not affected by glucocorticoid treatment. Kimberg and Yielding (1962) found that diethylstilbestrol inhibiced rabbit muscle pyruvate kinase activity by $60 \%$. A lesser degree of inhibition was obtained by $17 \beta$-estradiol, equilin, equilenin, 17aestradiol, and phenanthridine. Other steroids including deoxycorticosterone but not aldosterone were tested and found to be ineffective in inhibiting enzyme activity. It was pointed out, however, that this was a model system in vitro and that any biological importance is only a matter of speculation. 
Seasonal variations in pyruvate kinase activity of rat tissue have been reported by Tanaka et al. (1967), being highest during winter and lowest during summer. Temperature and light variability was eliminated by controlled environment. In addition these workers reported the isolation of two types of pyruvate kinase. Type $M$, having a molecular weight of 250,000 , was present in muscle, brain, heart, liver, kidney, fat pads and leucocytes. Type L, having a molecular weight of 208,300, was present only in liver and erythrocytes. The level of type L enzyme varied greatly under various physiological conditions, whereas that of type $M$ changed only slightly. 


\section{MATERIALS AND METHODS}

Preliminary investigations, involving 14 pigs $(12$ Poland China, 1 Hampshire and 1 Duroc), were conducted in order to select dosage levels and equilibration periods to be used in this study.

Following the preliminary investigations, 34 Poland China pigs, approximately $95 \mathrm{~kg}$., were divided into three trials during the fall of 1968 to study the influence of aldosterone, Aldactone and Aldactazide on pork muscle quality.

Treatments

Trial 1. Twelve pigs were randomly allotted to slaughter and treatment groups. Because of limited physical facilities, six pigs (three controls and three treated) were slaughtered on separate days. Approximately 18 hrs. before treatment, the pigs were hauled to the meats laboratory together to minimize stress effects due to transportation. Treated piqs were injected in the ear vein with 1.5 $\mathrm{mg}$. of aldosterone dissolved in $10 \mathrm{ml}$. of physiological saline. Control pigs were injected with $10 \mathrm{ml}$. of physiological saline. All pigs were allowed to remain undisturbed for an hour and a half equilibration period imme.. diately prior to slaughter. 
Trial 2. Ten pigs were randomly allotted to slaughter groups of six and four pigs, respectively. The group of six pigs was divided into two equal treatment groups of three pigs each; while the group of four pigs was divided into two equal treatment groups of two pigs each. Animals were transported to the meats 1 aboratory about $18 \mathrm{hrs}$. before treatment as in Trial 1. One treatment group of each slaughter group received an oral drench of $250 \mathrm{mg}$. of Aldactone, while the other two treatment groups received distilled water. After a $30 \mathrm{~min}$. equilibration period, pigs were stressed for $30 \mathrm{~min}$. using an electric prod, and slaughtered immediately.

Trial 3. Twelve pigs were randomly allotted to slaughter and treatment groups. Six pigs (three controls and three treated) were slaughtered on separate days. About $18 \mathrm{hrs}$. before treatment, the pigs were hauled to the meats laboratory as in previous trials. Treated pigs received an oral drench of $500 \mathrm{mg}$. of Aldactazide, while the controls received a drench of distilled water. After a 30 min. equilibration period, the pigs were stressed for 30 min. and then slaughtered.

\section{Carcass Handling and Sampling}

Following the administration of the various treatments, all animals were handled similarly. The pigs were slaughtered in the Louisiana State University Meats 
Laboratory and dressed according to conventional procedures. Special consideration was given to minimizing the time intervals from exsanguination to chill room. Serum samples for sodium and potassium determinations were collected at the time of exsanguination, taking care to avoid contamination. Muscle samples for sodium and potassium determinations were taken from the longissimus dorsi muscle at the 12 th rib just prior to placing the carcass in the chill room. Upon entering the chill room, temperature of ham and loin muscles, and $\mathrm{pH}$ of the loin muscles were recorded every $15 \mathrm{~min}$. for the first hour, every $30 \mathrm{~min}$. for the next 2 hrs., every hour for the next 3 hrs., and at $24 \mathrm{hrs}$. after exsanguination. Temperature was measured with a YSI (Yellow Spring Instrument) Model 47 tele-thermometer. Measurements of $\mathrm{pH}$ were accomplished by inserting a semimicro combination electrode (Corning) into the longissimus dorsi muscle and recording the value, adjusted for muscle temperature, from a Leeds \& Northrup Model $7401 \mathrm{pH}$ meter. After the carcasses had chilled for $24 \mathrm{hrs}$. at $3^{\circ} \mathrm{C}$, they were cut according to conventional procedures. Subjective quality scores were applied according to Wisconsin Pork Quality Standards (Anon., 1963) by a three-member panel. Following cutting and the application of the subjective quality scores, the 1 . dorsi muscle was sampled again for objective measures of quality, namely water binding capacity and protein turbidity. All samples were processed as soon 
as they were collected.

Sodium and Potassium Determination

Serum and muscle sodium and potassium were determined utilizing a Coleman Model 21 Flame Photometer with values being recorded from a direct reading scale panel (Cat 21-400) on a Coleman Model 22 Galv-0-Meter.

Serum Preparation. Serum samples were prepared for sodium and potassium determinations according to the procedures outlined in the operating Directions for the Coleman Model 21 Flame Photometer (Coleman Manual D-332, 1962).

Muscle Preparation. Muscle samples were trimmed to remove all external fat and connective tissue. Samples were ground through a $5 \mathrm{~mm}$. plate of a laboratory size food grinder which had been rinsed several times with distilled water, several times with deionized distilled water, and several times with acetone. Cations were removed from the muscle by the TCA (trichloroacetic acid) extraction procedure of Mounib and Evans (1957), as modified by Kirton and Pearson (1963). TCA extraction was carried out on triplicate samples and readings obtained from appropriate dilutions. Direct readings were mathematically converted so as to be expressed as ppm. 
Water Binding Determination

Muscle samples were trimmed of all external fat and connective tissue and ground through a $5 \mathrm{~mm}$. plate of a laboratory size food grinder. Water binding was determined using a modification of the procedure by Wierbicki et al. (1957). Duplicate 25 gram samples of fresh muscle were placed above a fritted disc in the upper portion of specially designed, calibrated centrifuge tubes. Vented rubber stoppers were placed in the tubes. Tubes were immersed to 0.9 their length in a $70^{\circ} \mathrm{C}$ water bath for $30 \mathrm{~min}$, after which they were allowed to $\operatorname{cool}$ at $25^{\circ} \mathrm{C}$ for $10 \mathrm{~min}$, and then centrifuged at $170 \times \mathrm{g}$ for $10 \mathrm{~min}$. The volume of fluid expressed during heating and centrifugation was read directly. This volume as a ratio to the gm. of moisture in the sample was expressed as percent moisture loss.

Protein Turbidity Determination

Samples were taken from the trimmed, ground muscle used to supply samples for water binding determinations. Protein turbidity was determined by the transmission value method described by Hart (1962). Duplicate $10 \mathrm{gm}$. samples were homogenized in $30 \mathrm{ml}$. of cold distilled water for 5 min. in a cold room at $4{ }^{\circ} \mathrm{C}$. The homogenate was transferred to a centrifuge tube, made to a total volume of $40 \mathrm{ml}$. With cold distilled water, thoroughly mixed, and held at $4{ }^{\circ} \mathrm{C}$ for $24 \mathrm{hrs}$. It was then centrifuged for $20 \mathrm{~min}$. and filtered 
through Whatman \#52 filter paper. One ml. of the clear filtrate was mixed with $5 \mathrm{ml}$. of a citric acid-sodium phosphate buffer $\left(9.35 \mathrm{ml}\right.$. of $0.2 \mathrm{M} \mathrm{Na}_{2} \mathrm{HPO}_{4} \mathrm{plus} 10.65 \mathrm{ml}$. of 0.1 M citric acid) at $\mathrm{pH}$ 4.6. This mixture was held at $20^{\circ} \mathrm{C}$ for $30 \mathrm{~min}$. The protein turbidity of this mixture was read as percent transmission in a Beckman DB spectrophotometer which was standardized against a blank of $1 \mathrm{ml}$. of muscle extract in $5 \mathrm{~m} 1$. Of distilled water. Normal muscle was expected to give a transmission value of $0-20$ while severe PSE muscles had values of 80-100.

\section{Statistical Analyses}

This experiment was designed as a randomized complete block with more than one observation per treatment (Steel and Torrie, 1960). However, in order to take advantage of physical facilities and minimize temperature variation and time from exsanguination to chill room, data were collected on paired pigs (a control and a treated) within a block. This imposed a $3 \times 2$ factorial arrangement upon the randomized complete block design, with periods (paired pigs) and treatments as main effects and slaughter dates as blocks. The variables for trials 1 and 3 were analyzed using the above analysis. However, due to disproportionate subclass numbers in Trial 2, these data were analyzed by least-squares procedure (Harvey, 1960). Means and standard errors are cited in the text; and individual observations 
are presented in the appendices.

Source of Compounds

The treatment compounds in this study were obtained from the following sources:

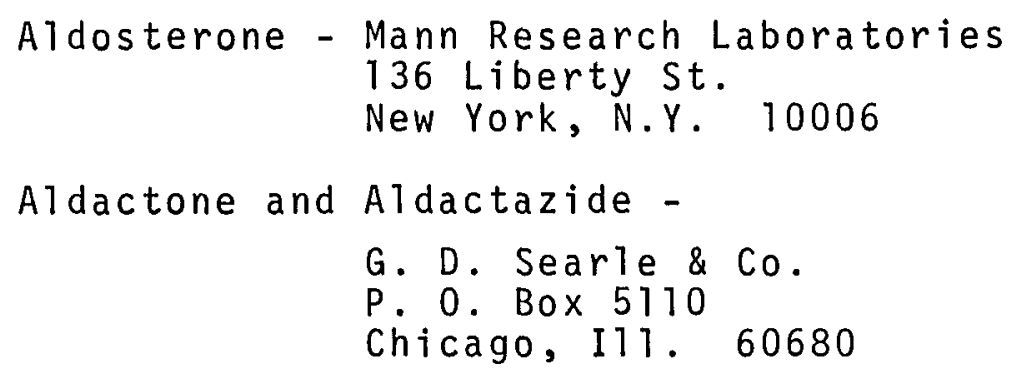

\section{Pyruvate Kinase Trial}

Four Hampshire pigs, approximately $95 \mathrm{~kg}$., were used to observe differences in the activity of pyruvate kinase from the liver and muscle of normal and PSE pigs. Two pigs received, as nearly as possible, identical treatment to those of Trial 1 and two pigs received the treatment of Trial 3. Within 5 min. after exsanguination, samples were removed from the liver and 1 . dorsi muscle, and chilled as rapidly as possible in crushed ice. Samples were ground through a $5 \mathrm{~mm}$. plate of a laboratory size food grinder, the head of which had been chilled in a blast freezer at $-29^{\circ} \mathrm{C}$.

The enzyme was isolated and assayed according to the procedure described by Tanaka et al. (1967). Three gm. of liver was homogenized in $10 \mathrm{ml}$. of cold $\left(4^{\circ} \mathrm{C}\right) \mathrm{KCl}$ solution $(0.15 \underline{M})$ containing $\mathrm{MgSO}_{4}(0.005 \mathrm{M})$ and EDTA (0.001 M). 
The homogenate was centrifuged at $105,000 \times \mathrm{g}$ for $60 \mathrm{min.;}$ and the supernatant used for assay of pyruvate kinase activity and protein determination. Simultaneously, $1.5 \mathrm{gm}$. of muscle tissue was homogenized in $13.5 \mathrm{ml}$. of the above solution, centrifuged as above, and the supernatants used as described with the liver. Pyruvate kinase was assayed by measurement of pyruvate formed from phosphoenolpyruvate in the presence of ADP with 2,4-dinitrophenylhydrazine, according to a modification of the method of Kimberg and Yielding (1962). The composition of the assay mixture was as follows: $50 \underline{\mu M}$ tris (hydroxymethy 1)-aminomethane, $200 \mu \mathrm{M}$ phosphoenolpyruvate, $200 \mu \mathrm{M} \mathrm{ADP}, 5 \mu \mathrm{M} \mathrm{MgSO}{ }_{4}$, $100 \mu \mathrm{M} \mathrm{KCl}$, total volume $1.0 \mathrm{ml}$, $\mathrm{pH} \mathrm{7.5.} \mathrm{The} \mathrm{addition} \mathrm{of}$ $0.1 \mathrm{ml}$. of supernatant to $1.0 \mathrm{ml}$. of assay mixture started the reaction. After $3 \mathrm{~min}$. incubation at $37^{\circ} \mathrm{C}, 0.2 \mathrm{ml}$. of the reaction mixture was added to $0.5 \mathrm{ml}$. of 2,4dinitrophenylhydrazine $(0.0125 \%$ in 2 N HCl) and allowed to stand $10 \mathrm{~min}$. at $37^{\circ} \mathrm{C}$. Then $1.2 \mathrm{ml}$. of $2.4 \mathrm{~N} \mathrm{NaOH}$ containing 0.001 EDTA was added. After allowing $10 \mathrm{~min}$. for full color development, optical density was measured at $510 \mathrm{m \mu}$ on a Beckman DB spectrophotometer. Blanks were run in identical fashion, only omitting ADP from the assay mixture. A standard curve was obtained using sodium pyruvate in the following concentrations $(\underline{\mu \mathrm{M} / \mathrm{ml}})$ ): $4.5,8.4,10.5$, 42,84 .

One unit of enzyme was expressed as the amount of 
enzyme which catalyzes the formation of 1 4mole of pyruvate per minute under the above conditions. The specific activity was expressed as units of enzyme per mg. of protein. Protein was obtained by multiplying 6.25 times the mg. of nitrogen determined by microkjeldahl and direct nesslerization. 


\section{RESULTS AND DISCUSSION}

\section{Preliminary Investigations}

Since a hyperproduction of aldosterone had been reported in the etiology of PSE porcine musculature (Henry et a1., 1958), it was of interest to determine if PSE musculature could be produced by the administration of this hormone, as well as prevented by the administration of an aldosterone-blocking agent.

The literature indicated that the normal daily secretion rate of aldosterone in man varied from 70 to $300 \mu \mathrm{g}$, and that plasma concentration of aldosterone in man ranged from 5 to $200 \mu \mathrm{g} / 100 \mathrm{ml}$. (Ross, 1965). Also, indications were that a delay of 45 to 90 minutes was necessary for aldosterone to become effective (Ross, 1965). Therefore, these preliminary investigations, using various dosages of aldosterone and various periods of equilibration, revealed that PSE musculature could be produced using a $10 \mathrm{ml}$. physiological saline injection containing $1.5 \mathrm{mg}$. of aldosterone, with an hour and a half equilibration period.

Preliminary investigations with an aldosteroneblocking agent were limited to the use of Aldactazide. Aldactazide was a combination of equal quantities of Aldactone (spironolactone) and hydrochlorothiazide, which act 
synergistically. Aldactone effects diuresis by blocking, through competitive inhibition, the sodium- and waterretaining and potassium-excreting effects on the distal renal tubules of aldosterone. Hydrochlorothiazide, a potent diuretic agent, promotes excretion of sodium and water primarily by inhibiting their absorption by the proximal renal tubules; and also it promotes excretion of potassium. The recommended dosage of Aldactazide for an adult man ranged from 50 to $200 \mathrm{mg} . / \mathrm{day}$. Therefore, the use of various dosages and equilibration periods indicated that in this study an oral drench of $500 \mathrm{mg}$. of Aldactazide in distilled water and a $30 \mathrm{~min}$. equilibration period prevented the development of PSE musculature resulting from a 30 min. stress period with an electric prod.

\section{Proposed Role of Aldosterone}

The primary function of aldosterone is to increase sodium retention and potassium excretion in the renal tubules of the kidney. In the reversal of glycolysis to form glucose-6-phosphate, ATP, available from aerobic oxidation of a fraction of lactic acid (via pyruvic acid and the citric acid cycle), must be provided to reverse the pyruvic kinase and phosphoglyceric kinase reactions. However, there is a rate limiting factor; pyruvic kinase is potassium dependent (White et al., 1964). PSE muscle occurs when there is a rapid rate of $\mathrm{pH}$ decline at a high 
temperature. Just before and at the time of exsanguination a certain amount of aerobic glycolysis is occurring within the muscle, therefore, oxidative phosphorylation and the production of ATP. Likewise, since considerable anaerobic glycolysis has occurred, the ratio of pyruvate to phosphoenolpyruvate is probably very high. Perhaps then in normal muscle, sufficient potassium is present for pyruvate kinase activity, reversing glycolysis and allowing a portion of the lactic acid from preslaughter exercise, excitement, etc., to go back into the Embden-Meyerhof pathway as other compounds, thereby decreasing the rate of $\mathrm{pH}$ drop post-mortem. In PSE muscle, aldosterone production has caused an increased excretion of potassium, reducing its availability for the reversal of glycolysis. Subsequently, pre-slaughter lactic acid would remain, plus the lactic acid which accumulates during post-mortem glycolysis, consequently a more rapid drop of $\mathrm{pH}$ at a high temperature.

Results of Trial 1

In this trial, an injection of $1.5 \mathrm{mg}$. of aldosterone was used to produce PSE musculature in Poland China pigs. Figures 1 and 2 show representative hams and loins from the control and aldosterone treated pigs, respectively. Note the uniform color, firm texture, and dry appearance of the face of the ham in Figure 1 as compared to the pale color, soft texture and watery appearance displayed by the 


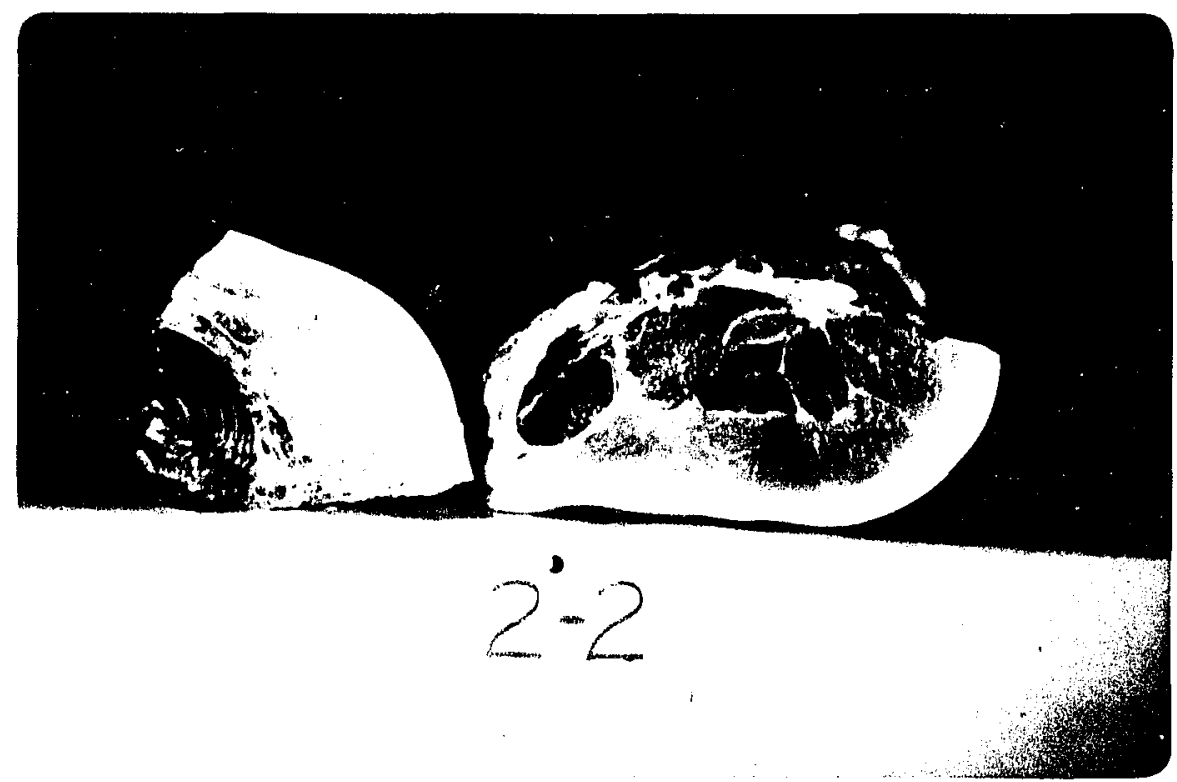

FIGURE 1. HAM AND LOIN OF CONTROL FOR TRIAL 1

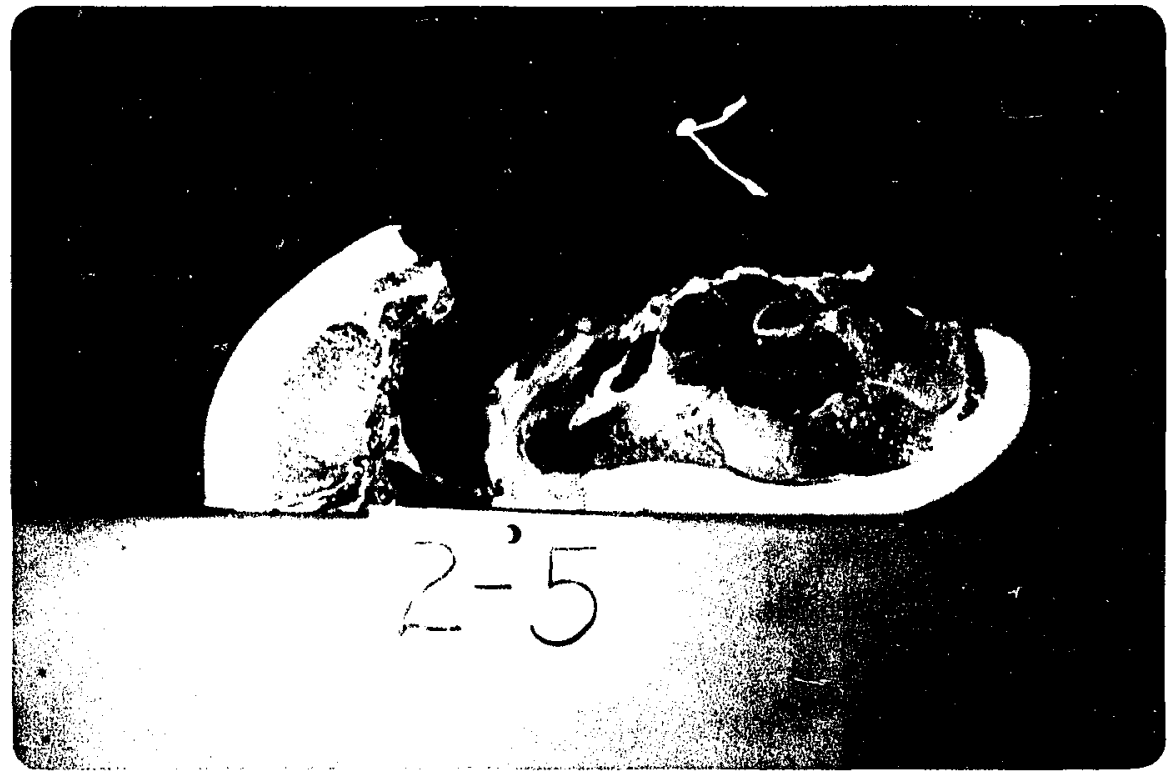

FIGURE 2. HAM AND LOIN OF ALDOSTERONE TREATED FOR TRIAL 1 
muscles in the lower portion of the ham in Figure 2. Due to the lighting on these figures, it is difficult to detect differences between the 1 . dorsi muscles, however, close examination revealed more evidence of moisture on the surface of this muscle in Figure 2 than in Figure 1 .

Means and standard errors for subjective and objective quality evaluations are presented in Table 1 . The injection of $1.5 \mathrm{mg}$. of aldosterone resulted in a highly significant $(P<.01)$ reduction in porcine muscle quality as measured by the Wisconsin Quality Score. The control anim mals had a quality score of 2.8 compared to 1.8 for the treated group. No significant differences were obtained for the objective measures of quality; however, trends were similar. The control group had a higher water binding capacity, losing $34.5 \%$ moisture, compared to $37.3 \%$ for the treated group. Likewise, the $29.4 \%$ transmission value from the protein turbidity test for the controls indicated a greater sarcoplasmic protein content in that group than in the treated group ( $40.6 \%$ transmission), reflecting superior quality.

Table 2 contains the means and standard errors for serum and muscle sodium and potassium for this trial. No statistically significant differences were obtained for either serum or muscle sodium and/or potassium. Serum sodium was sightiy higher for the controls (157.8 meq./1) than for the aldosterone treatment (156.3 meq./1); whereas 
TABLE 1. MEANS AND STANDARD ERRORS FOR SUBJECTIVE AND OBJECTIVE QUALITY EVALUATIONS

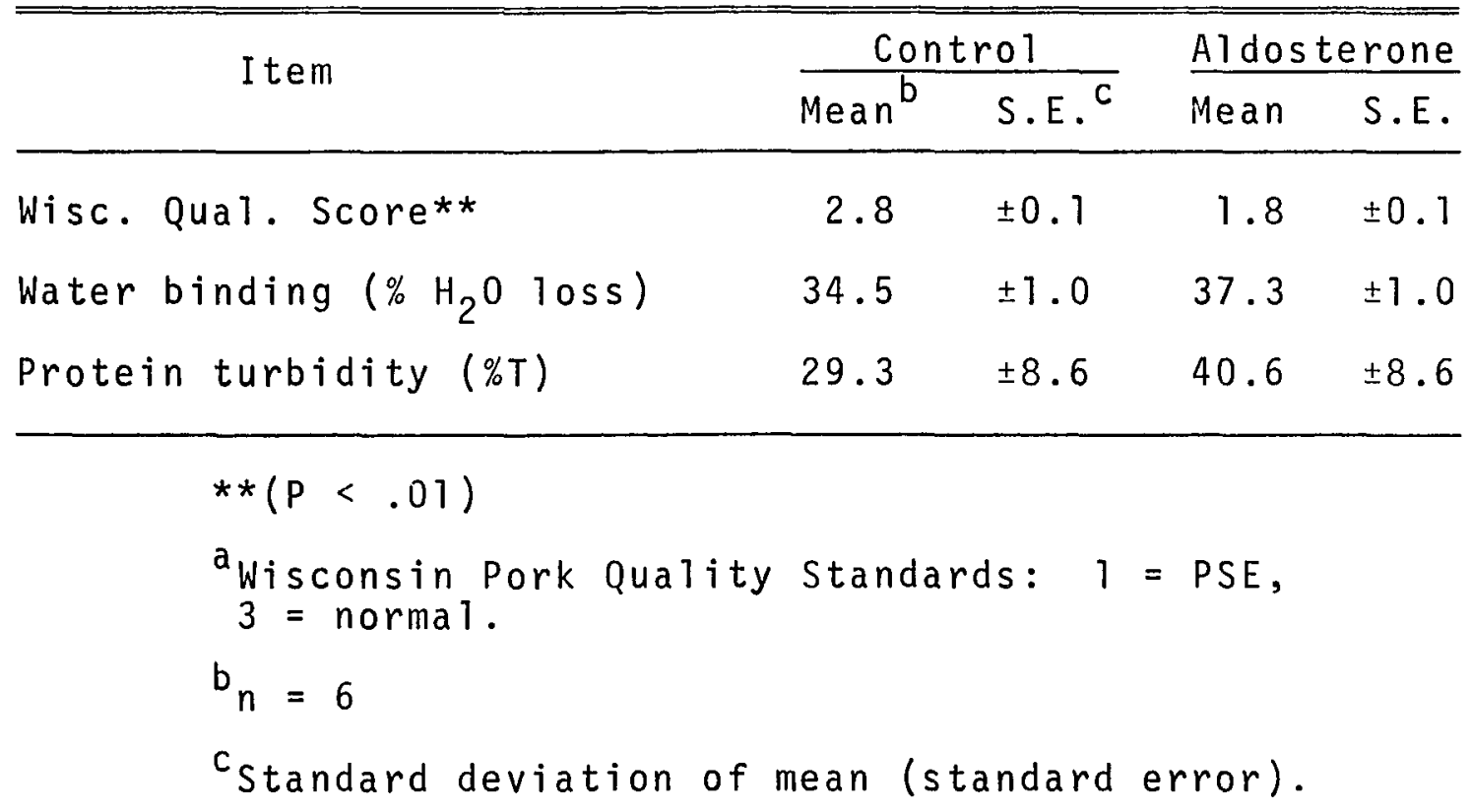


TABLE 2. MEANS AND STANDARD ERRORS

FOR SODIUM AIND POTASSIUM

\begin{tabular}{|c|c|c|c|c|}
\hline \multirow[b]{2}{*}{ Item } & \multicolumn{2}{|c|}{ Control } & \multicolumn{2}{|c|}{ Aldosterone } \\
\hline & Mean ${ }^{a}$ & S.E. & Mean & S.E. \\
\hline Serum $\mathrm{Na}^{+}$, meq./1 & 157.8 & \pm 1.4 & 156.3 & \pm 1.4 \\
\hline Serum $K^{+}$, meq./1 & 5.9 & \pm 0.2 & 5.6 & \pm 0.2 \\
\hline Muscle $\mathrm{Na}^{+}, \mathrm{ppm}$ & 433.3 & \pm 15.3 & 455.1 & \pm 15.3 \\
\hline Muscle $k^{+}, p p m$ & $4,337.8$ & \pm 59.8 & $4,265.4$ & \pm 59.8 \\
\hline
\end{tabular}


potassium was lower for the treated group (5.6 meq./1) than for the controls $(5.9 \mathrm{meq} / 1)$. iluscle sodium content was higher for the treated group (455.1 ppm) than for the controls (433.3 ppm), while muscle potassium content was lower for the treated group $(4,265.4 \mathrm{ppm}$ vs. 4,337.8 ppm).

There was little or no relationship between temperature and $\mathrm{pH}$ values and the development of PSE muscle in this study. Therefore, values are recorded individually in appendix tables 7,8 , and 9 , and not incorporated into the text.

\section{Results of Trial 2}

An oral drench of $250 \mathrm{mg}$. of Aldactone, a dosage equivalent to $500 \mathrm{mg}$. of Aldactazide, was used in an attempt to prevent the production of PSE musculature in Poland China pigs resulting from a $30 \mathrm{~min}$. stress period with an electric prod. Representative hams and loins from the control group and the Aldactone treated group are shown in Figures 3 and 4 , respectively. The hams and 10 ins in these figures are quite comparable with regard to their expression of PSE characteristics. Disregarding the effect of lighting in Figure 4 , the texture appeared to be somewhat softer than that of Figure 3 , as evidenced by the protruding muscles in the lower portion of the face of the ham. This was unexpected since Aldactone was supposed to prevent the development of PSE musculature. 


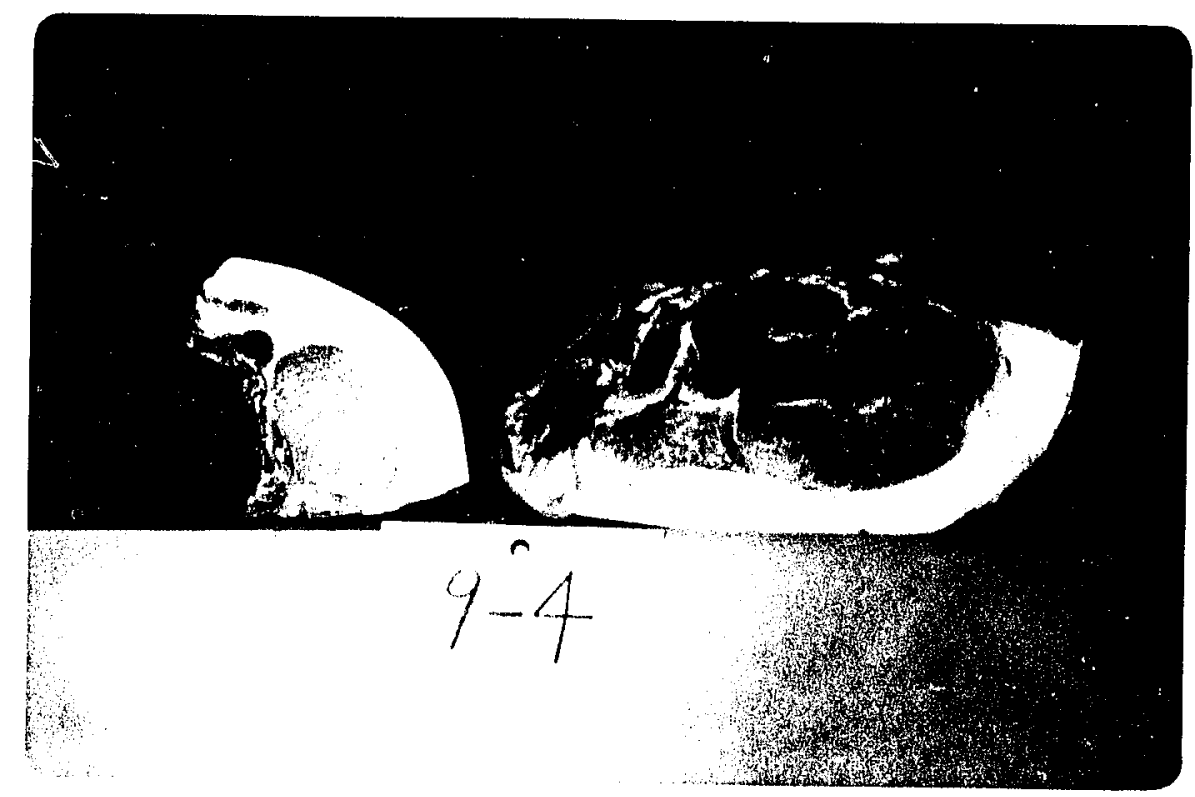

FIGURE 3. HAM AND LOIN OF CONTROL FOR TRIAL 2

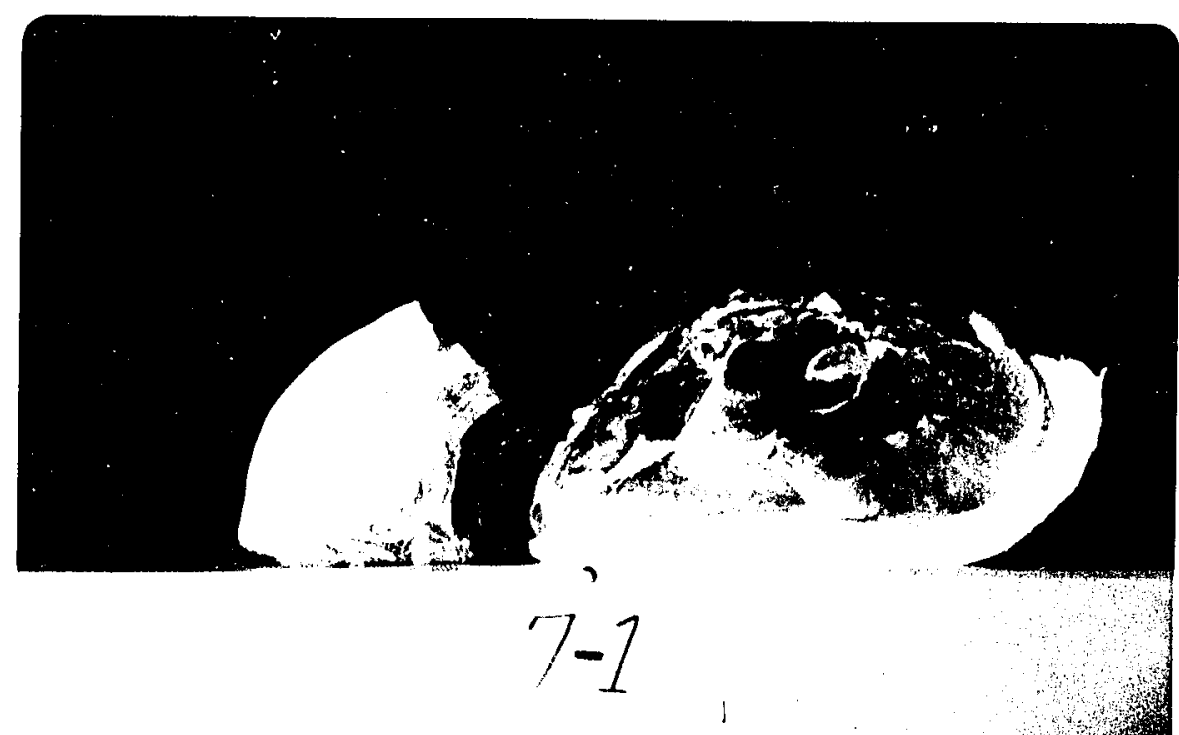

FIGURE 4. HAM AND LOIN OF ALDACTONE TREATED FOR TRIAL 2 
No significant differences were obtained for either the subjective or objective evaluations of quality (Table 3). The mean Wisconsin Quality Score was essentially the same for the treated group (2.1) as for the controls (2.0). However, objective measures indicated a slight advantage in quality for treatment. The treated group had a slightly lower percent moisture loss (42.6 vs. $45.1)$ and a lower protein turbidity value $(68.0 \%$ T vs. $92.3 \%$ T) .

Table 4 contains the least squares means and standard errors for sodium and potassium content of serum and muscle. No statistically significant differences were found for any of these measurements. Serum sodium was higher in the treated group, while serum potassium was higher in the control group. Muscie sodium was lower in the treated group (470.0 ppm vs. $477.6 \mathrm{ppm})$, while muscle potassium was higher in the treated group $(4,209.5 \mathrm{ppm}$ vs. $4,113.0 \mathrm{ppm})$.

Results of Trial 3

An oral drench of $500 \mathrm{mg}$. of Aldactazide was used to prevent the development of PSE musculature in Poland China pigs resulting from stress with an electric prod. Figures 5 and 6 represent the hams and loins of the control and Aldactazide treated pigs, respectively. Examination of Figure 5 reveals that the muscles in the outer portion of 
TABLE 3. LEAST-SQUARES MEANS AND STANDARD ERRORS FOR SUBJECTIVEA AND OBJECTIVE QUALITY

EVALUATIONS

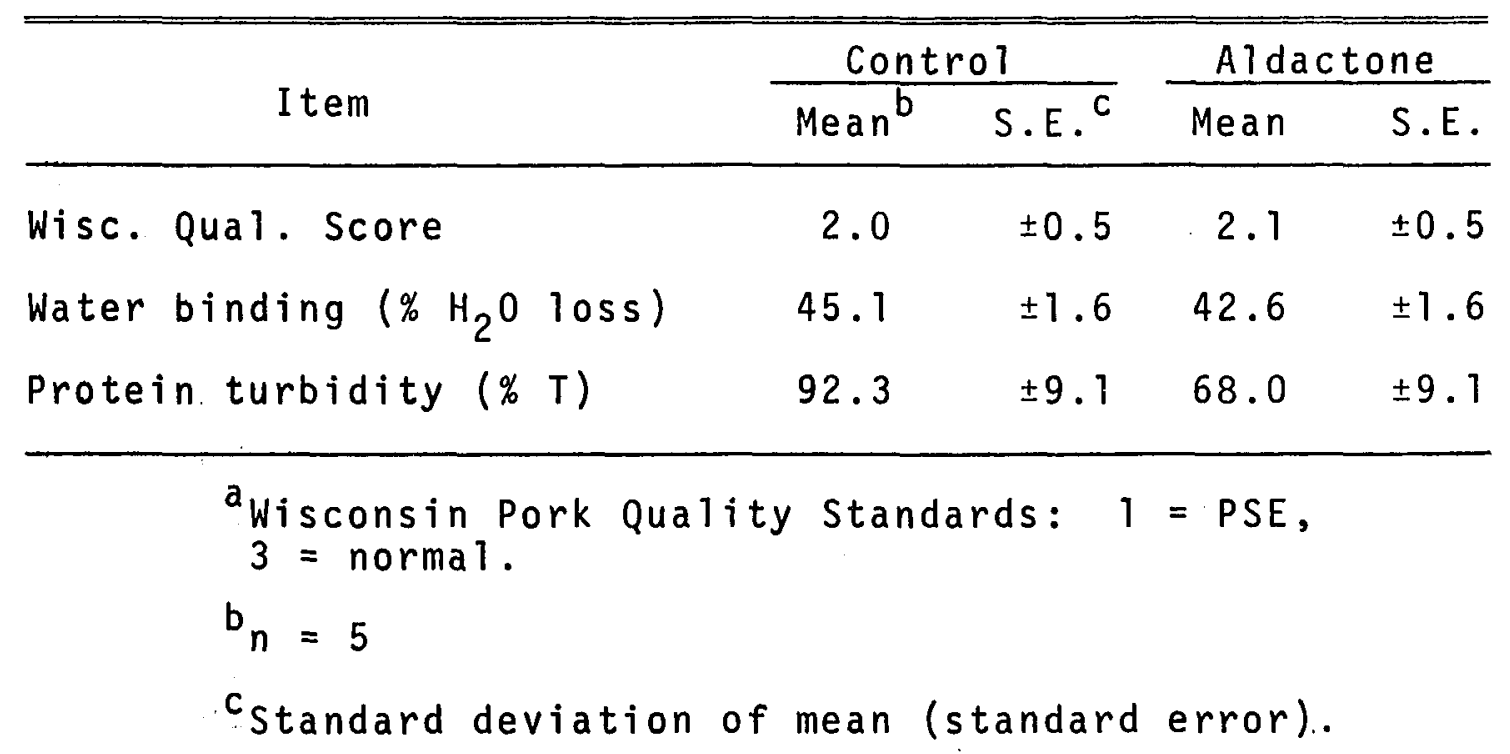


TABLE 4. LEAST-SQUARES MEANS AND STANDARD ERRORS FOR SODIUM AND POTASSIUM

\begin{tabular}{|c|c|c|c|c|}
\hline \multirow{2}{*}{ I tem } & \multicolumn{2}{|c|}{ Control } & \multicolumn{2}{|c|}{ Aldactone } \\
\hline & Mean ${ }^{a}$ & $S \cdot E .^{b}$ & Mean & S.E. \\
\hline Serum $\mathrm{Na}^{+}$, meq./1 & 165.1 & \pm 2.4 & 166.8 & \pm 2.8 \\
\hline Serum $K^{+}$, meq./1 & 8.6 & \pm 1.1 & 7.9 & \pm 1.1 \\
\hline Muscle $\mathrm{Na}^{+}, \mathrm{ppm}$ & 477.6 & \pm 15.9 & 470.9 & \pm 15.9 \\
\hline Muscle $\mathrm{K}^{+}, \mathrm{ppm}$ & $4,113.0$ & \pm 73.8 & $4,209.5$ & \pm 73.8 \\
\hline
\end{tabular}




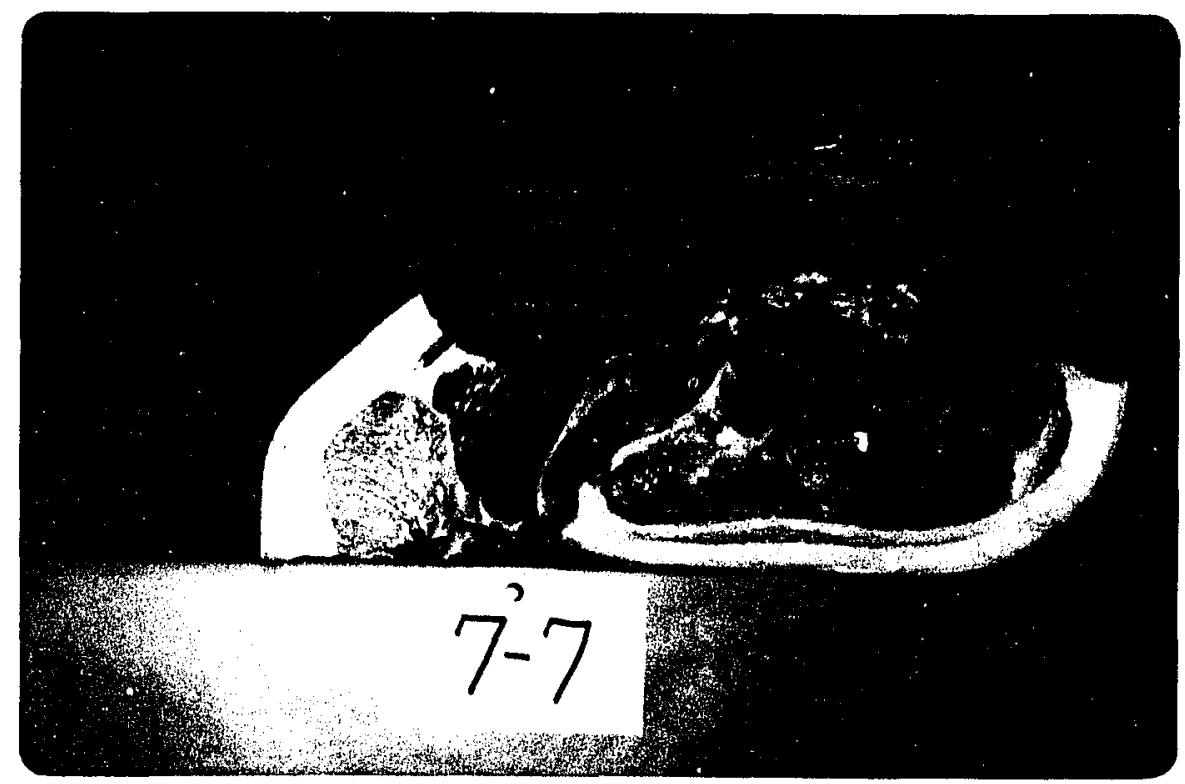

FIGURE 5. HAM AND LOIN OF CONTROL FOR TRIAL 3

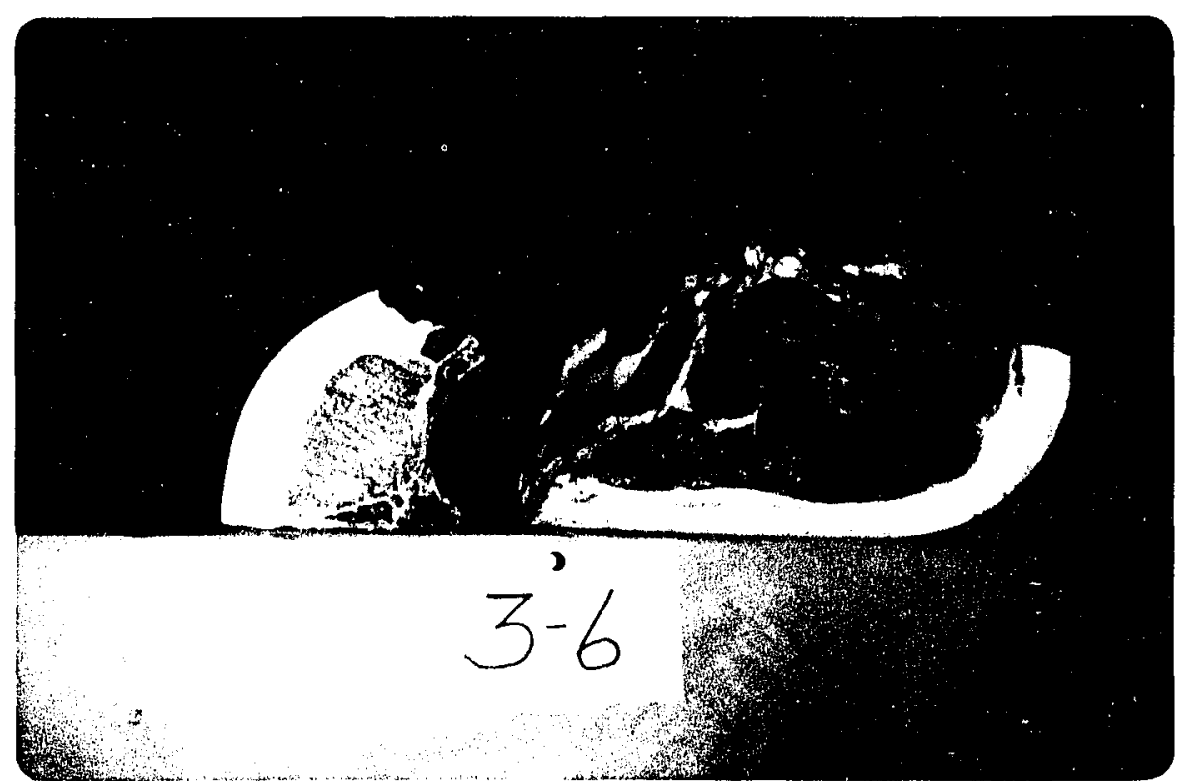

FIGURE 6. HAM AND LOIN OF ALDACTAZIDE TREATED FOR TRIAL 3 
the ham face were lighter in color, softer in texture and exuding more juice than those in Figure 6 . Also, the 1 . dorsi muscle of Figure 5 was soft and watery compared to that of Figure 6 .

The oral administration of $500 \mathrm{mg}$. of Aldactazide significantly $(P<.05)$ increased the Wisconsin Pork Quality Score from 1.2 for the controls to 2.5 (Table 5). Although not statistically significant, a decrease in protein turbidity from $93.8 \% \mathrm{~T}$ for the controls to $70.5 \% \mathrm{~T}$ for the treated group indicated an improvement in quality. However, no differences were obtained for water-holding capacity $(43.9 \%$ for controls vs. $43.1 \%$ for treated).

Heans and standard errors for sodium and potassium of serum and muscle are shown in Table 6. Values varied erratically. Serum and muscle sodium contents were higher in the treated group (164.3 meq./1, 451.7 ppm) than in the controls (159.8 meq./1, 414.8 ppm). Likewise, serum and muscle potassium contents were lower in the treated group (7.1 meq./1,3,944.8 ppm) than in the controls ( 8.0 meq./1, $3,968.2 \mathrm{ppm})$. However, none of these values differed significantly.

A significant $(P<.05)$ period effect was obtained for serum potassium in this trial (appendix table 28). 
TABLE 5. MEANS AND STANDARD ERRORS FOR SUBJECTIVE ${ }^{a}$ AND OBJECTIVE QUALITY EVALUATIONS

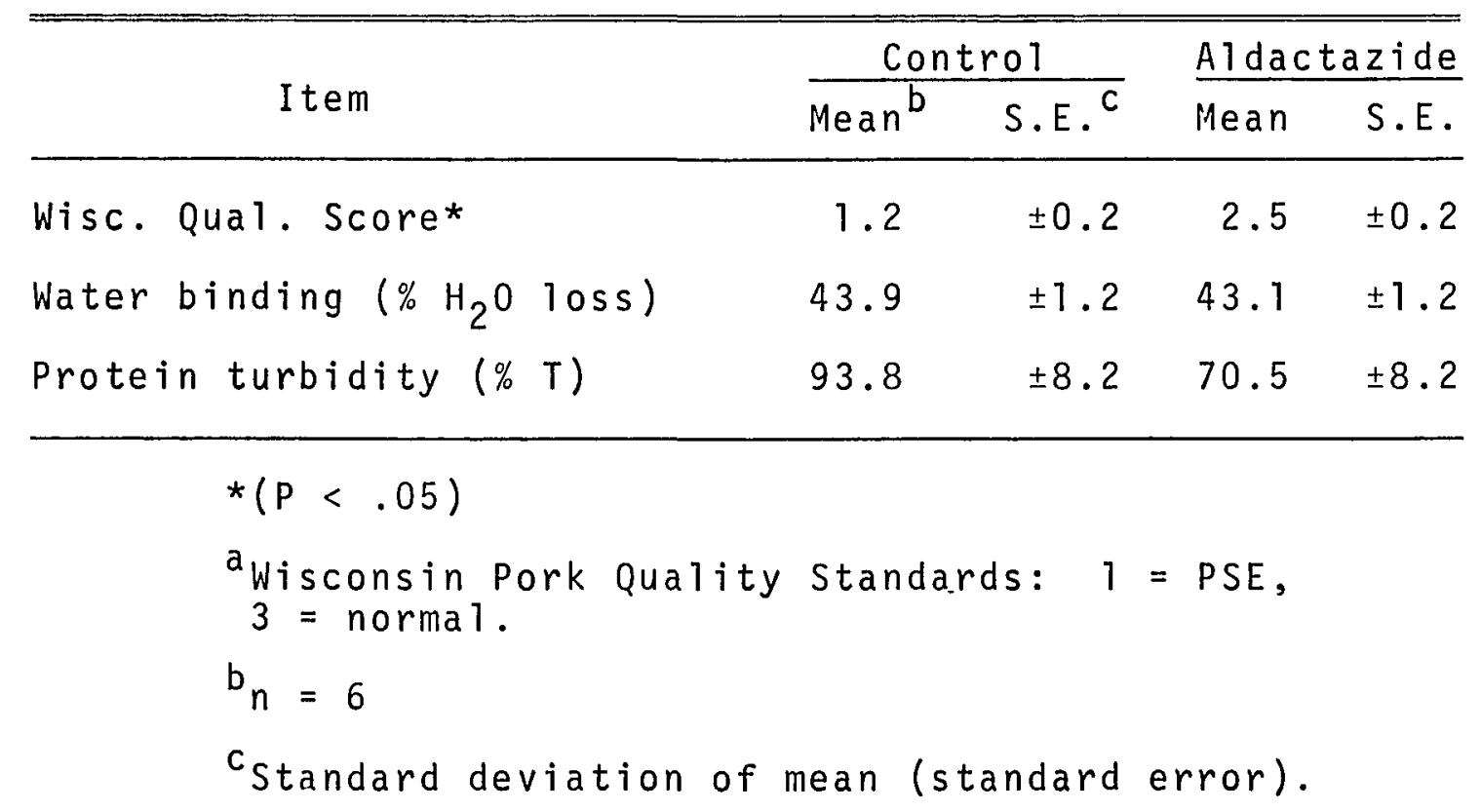


TABLE 6. MEANS AND STANDARD ERRORS

FOR SODIUM AND POTASSIUM

\begin{tabular}{|c|c|c|c|c|}
\hline \multirow[b]{2}{*}{ Item } & \multicolumn{2}{|c|}{ Control } & \multicolumn{2}{|c|}{ Aldactazide } \\
\hline & Mean ${ }^{a}$ & S.E. & Mean & S.E. \\
\hline Serum $\mathrm{Na}^{+}$, meq./7 & 159.8 & \pm 5.0 & 164.3 & \pm 5.0 \\
\hline Serum $K^{+}$, meq./1 & 8.0 & \pm 0.5 & 7.1 & \pm 0.5 \\
\hline Muscle $\mathrm{Na}^{+}, \mathrm{ppm}$ & 474.8 & \pm 13.3 & 451.7 & \pm 13.3 \\
\hline Muscle $\mathrm{K}^{+}$, ppm & $3,968.2$ & \pm 66.6 & $3,944.8$ & \pm 66.6 \\
\hline
\end{tabular}

$a_{n}=6$

${ }^{b}$ standard deviation of mean (standard error). 
Discussion of Trials

The production of PSE musculature in Trial 1 with the injection of aldosterone and the prevention in Trial 3 with Aldactazide are in agreement with work of Henry et al. (1958), reporting pigs with PSE musculature had hyperproduction of aldosterone. The failure to report an increase in the Wisconsin Pork Quality Score, and the small advantage cited in objective measures of quality for the treatment in Trial 2, can possibly be attributed to the fact that Aldactone alone lacked the synergistic capabilities expressed by Aldactazide.

The objective measures of quality, even though they were not statistically significant, were in accord with expected results. Aldosterone decreased the water binding capacity of the 1 . dorsi muscle while the blocking agents increased this measurement, characteristics which have been shown to be related to PSE and normal musculature, respectively (Wismer-Pedersen, 1959; Wismer-Pedersen and Briskey, 1961; Bendall and Wismer-Pedersen, 1962). Protein turbidity values also tended to substantiate the production of PSE musculature with aldosterone and the prevention with a blocking agent. This procedure is based on the fact that in exudative meat the sarcoplasmic proteins have been denatured, resulting in a lower quantity of water soluble proteins than in normal meat. Therefore, the percent transmission will be higher for PSE musculature than for 
normal muscle. According to Hart (1962), transmission values for normal meat are expected to be $0-20 \%$ while those for PSE meat are between $80-100 \%$. This study revealed that these values were indicative only if extremes in each classification were encountered. However, turbidity values for intermediate quality score muscle did not array in a linear order. This is in agreement with Ockerman and Cahill (1968) who reported that if a given percent transmission value was used to separate acceptable and unacceptable quality, a large percent of the carcasses disqualified by this procedure also would be rated unacceptable by visual means. However, some carcasses rated unacceptable by visual means would not necessarily be rated unacceptable by this procedure.

No statistically significant differences were obtained for sodium and potassium contents of serum or muscle for any of the trials. Serum sodium values were higher in the controls in Trial 1 and in the treated groups of Trials 2 and 3 . Since aldosterone is supposed to increase sodium retention, this was unexpected, but it is in agreement with serum values reported by Henry et al. (1958) and plasma values reported by Topel et al. (1967). The occurrence of lower serum potassium values for the aldosterone treatment of Trial 1 agrees with Henry et al. (1958) and Topel et al. (1967). However, the higher values for the controls of Trials 2 and 3 are contradictory to the results of the 
above authors.

Muscle sodium and potassium values for Trials 1 and 2 show small differences, but are in agreement with results reported by Henry et al. (1958), and show the same trends as data reported by Topel et a1. (1967). However, those of Trial 3 are contradictory to the above reports.

The results of these trials with regard to the potassium content of muscle failed to support the proposed role of aldosterone in the etiology of PSE musculature. However, it should be kept in mind that the procedures used in this study were measuring total potassium in the muscle. No attempts were made to estimate intracellular or extracellular potassium components. It is possible that an alteration in intracellular potassium concentration could occur which was not detected with the present techniques employed.

Furthermore, a point for consideration is the magnitude of the decrease in potassium concentration necessary to inactivate the pyruvate kinase reaction in porcine muscle. If this was known, it would give an indication of the sample size necessary to detect these differences.

\section{Pyruvate Kinase Trial}

In view of the fact that the differences in muscle potassium content did not support the proposed role of a 1 dosterone in the etiology of PSE musculature, it was of 
interest to observe the pyruvate kinase activity of pigs. Four Hampshire pigs (intermediate in susceptibility to PSE musculature) were subjected to treatments similar to Trials 1 and 3 , and the pyruvate kinase activity was measured. None of the pigs developed PSE musculature, all having a Wisconsin Pork Quality Score of 3 . Table 7 contains the activity of pyruvate kinase found in the muscle and liver of these pigs. The specific activity of the muscle was greater for the aldosterone treated animal $(5,158.3)$ than for the aldosterone control $(4,509.8)$, while that of the Aldactazide control $(6,670.9)$ was greater than the treated $(4,240.6)$. The reverse was true for the activity of the liver enzyme, 289.9 vs. 348.7 and 364.3 vs. 533.1 , respectively. Results from these studies are not conclusive and cannot be extrapolated to the previous animals since differences in muscle quality were not consistent with other treatments. However, Kastenschmidt et al. (1968) reported that mass action ratios calculated from means of appropriate intermediates afforded consideration for a control in post-mortem glycolysis at the pyruvate kinase step. Therefore, some indication as to the activity of pyruvate kinase in pork muscle is of value. 
TABLE 7. PYRUVATE KINASE ACTIVITY OF PORK MUSCLE AND LIVER

\begin{tabular}{lcc}
\hline \multirow{2}{*}{ Treatment } & \multicolumn{2}{c}{ Specific Activitya } \\
\cline { 2 - 3 } Aldosterone Control & $4,509.8$ & Liver \\
Aldosterone Treated & $5,158.3$ & 289.7 \\
Aldactazide Control & $6,670.9$ & 364.3 \\
Aldactazide Treated & $4,240.6$ & 533.7 \\
\hline
\end{tabular}

$a_{\mu M}$ Pyruvate/ml./min./mg. Protein. 
SUMMARY

A study was designed to investigate the influence of aldosterone and aldosterone-blocking agents (Aldactone and Aldactazide) on porcine muscle quality, and to obtain some insight into the role or mode of action of aldosterone in the etiology of PSE musculature. Fourteen pigs were used in preliminary investigations to establish dosage levels and equilibration periods for the compounds used. Following this, 34 Poland China pigs, approximately $95 \mathrm{~kg}$. , were divided into three trials of 12,10 and 12 pigs each, and treated with aldosterone, Aldactone and Aldactazide, respectively. The pigs in the latter two trials were stressed for 30 minutes. Animals were slaughtered; serum and muscle sodium and potassium samples were taken; carcasses were chilled; and subjective and objective quality evaluations were determined.

Pyruvate kinase activity of porcine muscle and liver was obtained from four animals.

Under the conditions of this experiment, the following conclusions seem justifiable:

1. The intravenous injection of $1.5 \mathrm{mg}$. of aldosterone resulted in a highly significant $(P<.01)$ reduction in Wisconsin Pork Quality Score, and a trend toward 
decreased quality as measured by objective methods.

2. The oral administration of $500 \mathrm{mg}$. of Aldactazide caused a significant $(P<.05)$ increase in Wisconsin Pork Quality Score and a decrease in protein turbidity, both indicating superior muscle quality.

3. The oral administration of $250 \mathrm{mg}$. of Aldactone tended to improve muscle quality as measured by objective methods but not as measured by the subjective method.

4. Serum and muscle sodium and potassium contents were not affected significantiy by any of the treatments imposed. The differences obtained were small and somewhat inconsistent.

5. Aldosterone was postulated to influence PSE conditions through its effect on muscle potassium, inactivating pyruvate kinase. However, muscle potassium values failed to substantiate this postulation. It was entirely possible that sampling methods for potassium were inadequate to properly evaluate this theory. 


\section{RECOMMENDATIONS FOR FUTURE RESEARCH}

Since aldosterone and aldosterone-blocking agents were found to affect PSE muscle conditions, further study is needed to elucidate the exact mechanisms involved. Areas of considerable interest would be:

1. The influence of aldosterone on muscle electro1ytes.

2. Improved techniques for studyina alterations of intracellular and extracellular electrolytes in muscle.

3. The influence of pyruvate kinase isozymes on ante-mortem and post-mortem glycolytic rates as related to muscle quality.

4. The influence of aldosterone on the activity of cyclic AMP and phosphorylase in various tissues.

5. The incorporation of radioisotopes, involving electrolytes and glycolytic intermediates, to elucidate the basic cause or causes of PSE musculature. 


\section{LITERATURE CITED}

Aberle, E. D. and R. A. Merkel. 1968. Physical and biochemical properties of porcine muscle as affected by exogenous epinephrin and prednisolone. J. Food. Sci. $33: 43$.

Anonymous. 1963. Pork quality standards. Wisc. Agr. Exp. Sta. Sp. But. 9.

Ballard, K., A. Lefer, and G. Sayers. 1960. Effect of aldosterone and of plasma extracts on a rat-heart1ung preparation. Amer. J. Physio1. 199:221.

Beck, J. C., E. E. McGarry, I. Dyrenfurth, and E. H. Venning. 1957. Metabolic effects of human and monkey growth hormone in man. Science 125:884.

Beecher, G. R., L. L. Kastenschmidt, R. G. Cassens, W. G. Hoekstra and E. J. Briskey. 1968. A comparison of light and dark portions of a striated muscle. J. Food Sci. 33:84.

Bein, H. J. and R. Jacques. 1960. The antitoxic effect of a 1dosterone. Experientia 16:24.

Benda11, J.R. and J. Wismer-Pedersen. 1962. Some properties of the fibrilliar proteins of normal and watery pork muscle. J. Food Sci. 27:144.

Bodwel1, C. E., A. M. Pearson, J. Wismer-Pedersen, and L. J. Bratzler. 1966. Post-mortem changes in muscle. II. Chemical and physical changes in pork. J. Food Sci. $31: 1$.

Boyer, P. D. 1962. Pyruvate kinase. The Enzymes. vol. 6 ed. P. D. Boyer, H. Lardy and K. Myrbäck. Academic Press. New York. p. 95.

Bray, R. W. 1966. Pork quality--definition, characterization and significance. J. Animal Sci.24:839.

Breidenstein, B. C. 1963. The current status of pork quality research. Proc. 13th Recip. Meat Conf. $13: 261$. 
Briskey, E. J. 1957. Some factors contributing to pork quality. Proc. 10th Recip. Meat Conf. 10:146.

Briskey, E. J. 1963. Influence of ante- and post-mortem handling practices on properties of muscle which are related to tenderness. Proceedings Meat Tenderness Symposium. Campbell Soup Company.

Briskey, E. J. 1964. Etiological status and associated studies of pale, soft, exudative porcine musculature. Advances in Food Res. 13:89.

Briskey, E. J., R. W. Bray, W. G. Hoekstra, P. H. Phillips and R. H. Grummer. 1959. The effect of exhaustive exercise and high sucrose regimen on certain chemical and physical pork ham muscle characteristics.

J. Animal Sci. 28:173.

Briskey, E. J., L. L. Kastenschmidt, J. C. Forrest, G. R. Beecher, M. D. Judge, R. G. Cassens and W. G. Hoekstra. 1966. Biochemical aspects of post-mortem changes in porcine muscle. J. Agr. Food Chem. 14:201.

Bücher, T. and G. Pfleiderer. 1959. Pyruvate kinase from muscle. Methods in Enzymology vol. I, ed. S. P. Colowick and N. 0. Kaplan. Academic Press Inc., New York.

Cassens, R. G. 1966. General aspects of postmortem changes. The Physiology and Biochemistry of Muscle as a Food. ed. by E. J. Briskey, R. G. Cassens, and J. C. Trautman. The University of Wisconsin Press. Madison. p. 181.

Drakota, Z. 1961. The ionic composition of various types of striated muscles. Physiol. Bohemoslov. 10:160.

Ellis, J. T. 1956. Necrosis and regeneration of skeletal muscles in cortisone-treated rabbits. Am. J. Pathol. 32:993.

Faludi, G., L. C. Mills and Z. W. Chayes. 1964. Effect of steroids on muscle. Acta Endocrinologica 45:68.

Genest, J., G. Lemieux, A. Davignon, E. Koiw, W. J. Nowaczynski, and P. Steyermark. 1956. Human arterial hypertension. State of mild chronic hyperaldosteronism. Science 123:503. 
Germuth, F. G., Jr., G. A. Nedzek, B. Ottinger and J. Oyama. 1951. Anatomic and histological changes in rabbits with experimental hypersensitivity treated with compound E and ACTH. Proc. Soc. Exp. Biol. Med. 76:177.

Gillett, T. A., A. M. Pearson, and A. H. Kirton. 1965. Variation in potassium and sodium in muscles of the pig. J. Animal Sci. 24:777.

Hart, P. C. 1962. The transmission value, a method for meat quality evaluation. Research Institute for Animal Husbandry, "Schoonoord," Zeist, The Netherlands (Mimeograph).

Harvey, W. R. 1960. Least-squares analyses of data with unequal subclass numbers. ARS 20-8.

Henry, M., J. D. Romani and L. Joubert. 1958. La myopathie exudative depigmentaire du porc maladie de 1 'adaptation essai pathogenique et consequences pratigues. Rev. Path. Gen. Phys. C1in. 696:355.

Judge, M. D., E. J. Briskey, W. G. Hoekstra, R. G. Cassens, J. D. Sink and J. C. Forrest. 1965. Thyroid I 131 uptake and serum protein-bound iodine in relation to pale, soft, exudative porcine muscle. J. Animal Sci. $24: 864$ (Abstr.).

Kachamar, J. F. and P. D. Boyer. 1953. Kinetic analysis of enzyme reactions. II. The potassium activation and calcium inhibition of pyruvic phosphoferase. J. Biol. Chem. 200:681.

Kagawa, C. M. 1964. Anti-aldosterone. Methods in Hormone Research vol. III, ed. R. I. Dorfman. Academic Press. New York. p. 351.

Kastenschmidt, L. L., G. R. Beecher, J. C. Forrest, W. G. Hoekstra, and E. J. Briskey. 1965. Porcine muscle properties A. Alteration of glycolysis by artificially induced changes in ambient temperature. J. Food Sci. 30:565.

Kastenschmidt, L. L., E. J. Briskey, and W. G. Hoekstra. 1964. Prevention of pale, soft, exudative porcine muscle through regulation of ante-mortem environmental temperature. J. Food Sci. 29:210. 
Kastenschmidt, L. L., W. G. Hoekstra and E. J. Briskey. 1968. Glycolytic intermediates and co-factors in "fast-" and "slow-glycolyzing" muscles of the pig. J. Food Sci. 33:151.

Kimberg, D. V. and K. L. Yielding. 1962. Structural and functional changes induced by diethylstilbestrol and certain steroid hormones. J. Biol. Chem. 237:3233.

Kirton, A. H., R. H. Gnaedinger and A. M. Pearson. 1963. Relationship of potassium and sodium content to the composition of pigs. J. Animal Sci. 22904.

Kirton, A. H. and A. M. Pearson. 1963. Comparison of methods of measuring potassium in pork and 1 amb and prediction of their composition from sodium and potassium. J. Animal Sci. 22:125.

Krimsky, I. 1959. Phosphorylation of pyruvate by the pyruvate kinase reaction and reversal of glycolysis in a reconstructed system. J. Biol. Chem. 234:232.

Kulwick, R., L. Feinstein and E. C. Anderson. 1958. Correlation of potassium-40 concentration and fatfree lean content of hams. Science 127:338.

Kulwick, R., L. Feinstein and C. Golumbic. 1960. Beta radioactivity of the ash in relation to the composition of ham. J. Animal Sci. 19:119.

Kulwick, R., L. Feinstein and C. Golumbic, R. L. Hines, W. R. Seymore and W. R. Kauffman. 1961. Relationship of gamma-ray measurements to the lean content of hams. J. Animal Sci. 20:497.

Lamson, E. T., F. Elmadjian, J. M. Hope, G. Pincus and D. Jorjorian. 1956. Aldosterone excretion of normal, schizophrenic and psychoneurotic subjects. J. Clin. Endocrinol. and Metab. 16:954.

Laragh, J. H. and W. G. Kelly. 1964. Aldosterone: its biochemistry and physiology. Advances in Metabolic Disorders 1:217. ed. Rachmiel Levine and Rolf Luft. Academic Press, New York.

Lardy, H. A. and J. A. Ziegler. 1945. The enzymantic synthesis of phosphopyruvate from pyruvate. J. Biol. Chem. 159:343. 
Lawrie, R. A. and R. W. Pomeroy. 1963. Sodium and potassium in pig muscle. J. Agr. Sci. 61:409.

Levy, J. V. and V. Richards. 1962. Effects of aldosterone on contractile and electrical properties of driven isolated rabbit atria. Proc. Soc. Exp. Biol. Med. $111: 602$.

Ludvigsen, J. 1954. Investigations into so called "muscular degeneration" in pigs (in Danish, English summary). Beretning fra Forsgslaboratoriet (Copenhagen). No. 272 , Paper No. 1 .

Marple, D. N., D. G. Topel and C. Y. Matsushima. 1968. Effect of preslaughter exercise on porcine muscle and plasma. J. Animal Sci. 27:1763 (Abstr.).

McQuate, J. T. and M. F. Utter. 1959. Equilibrium and kinetic studies of the pyruvic kinase reaction. J. Biol. Chem. 234:2151.

Merke1, R. A. 1968. Implication of the circulatory system in skeletal muscle to meat quality. Proc. $21 \mathrm{st}$ Recip. Meat Conf. $21: 204$.

Mildvan, A. S. and M. Cohn. 1965. Kinetic and magnetic resonance studies of the pyruvate kinase reaction. I. Divalent metal complexes of pyruvate kinase. J. Biol. Chem. 240:238.

Mildvan, A. S. and M. Cohn. 1966. Kinetic and magnetic resonance studies of the pyruvate kinase reaction. II. Complexes of enzyme, metal and substrates. J. Biol. Chem. 241:1178.

Mills, I. H., A. Casper and F. C. Bartter. 1958. On the role of the vagus in the control of aldosterone secretion. Science 128:1140.

Mounib, M. S. and J. V. Evans. 1957. Comparison between three methods used for preparation of tissues for determination of potassium and sodium. Analyst $82: 522$.

Ockerman, H. W. and V. R. Cahill. 1968. Water extractability of muscle proteins and factors which affect this procedure as a method of determining pork quality. J. Animal Sci. 27:31.

Radouco-Thomas, S. M. 1962. Compositions and methods for improving meat. U.S. Patent 3,042,529. 
Ross, E. J. 1965. Aldosterone and its antagonists. Clin. Pharma. and Therap. 6:65.

Sayre, R. N., E. J. Briskey and W. G. Hoekstra. 1963a. Alteration of post-mortem changes in porcine muscle by preslaughter heat treatment and diet modification. J. Food Sci. 28:292.

Sayre, R. N., E. J. Briskey and W. G. Hoekstra. 1963b. Effect of excitement, fasting and sucrose feeding on porcine muscle phosphorylase and post-mortem glycolysis. J. Food Sci. 28:472.

Sayre, R. N., E. J. Briskey, W. G. Hoekstra and R. W. Bray. 1961. Effect of presiaughter change to a cold environment on characteristics of pork muscle. J. Anima1 Sci. 20:487.

Simpson, S. A. and J. F. Tait. 1954. Aldosterone and its possible role in the general adaptation syndrome. Fourth Annual Report on Stress. ed. by Hans Selye and G. Heuser. Acta, Inc., Montreal. p. 206.

Simpson, S. A., J. F. Tait, A. Wettstein, R. Neher, J. von Euq, and T. Reichstein. 1953. Isolierung eines neuen kristallisierten Hormone aus Nebennieren mit besonders hohen Wirksamkeit auf den Mineral Stoffwechsel. Experientia $9: 333$.

Spink, W. W. and J. Vick. 1962. Canine endotoxin shock: reversal with aldosterone and angiotensin II (hypertensin). Proc. Soc. Exp. Biol. Med. 109:521.

Sreter, F. A. and G. Woo. 1963. Cell water, sodium and potassium in red and white mammalian muscles.

Am. J. Physiol. 205:1290.

Steel, R. G. D. and J. H. Torrie. 1960. Principles and Procedures of Statistics. McGraw-Hill Book Co., New York.

Suelter, C. H., R. Singleton, Jr., F. J. Kayne, S. Arrington, J. Glass and A. S. Mildvan. 1966. Studies on the interaction of substrate and monovalent and divalent cations with pyruvate kinase. Biochemistry $5: 131$.

Swift, C. E. and M. D. Berman. 1959. Factors affecting the water retention of beef. I. Variations in composition and properties among eight muscles. Food Technol. 13:365. 
Tanaka, T., Y. Harano, F. Sue and H. Morimura. 1967. Crystallization, characterization and metabolic regulation of two types of pyruvate kinase isolated from rat tissues. J. Biochem. 62:71.

Tanz, R. D. 1962. Studies on the inotropic action of aldosterone on isolated cardiac tissue preparations; including the effects of pH, ouabain and SC-8109. J. Pharmacol. Expt1. Therap. 135:71.

Tait, J. F., S. A. Simpson and H. Grundy. 1952. The effect of adrenal extract on mineral metabolism. Lancet $1: 122$.

Topel, D. G. 1968. Endocrine influence on microcirculation. Proc. 21st Recip. Meat Conf. 21:195.

Tope1, D. G. and R. A. Merke1. 1966. Effect of exogenous goitrogens upon some physical and biochemical properties of porcine muscle and adrenal glands.

J. Animal Sci. 25:1154.

Tope1, D. G. and R. A. Merkel. 1967. Effects of exogenous prednisolone and methylprednisolone upon plasma 17hydroxycorticosteroid levels and some porcine muscle characteristics. J. Animal Sci. 26:1017.

Tope1, D. G., R. A. Merkel and J. Wismer-Pedersen. 1967. Relationship of plasma 17-hydroxycorticosteroid levels to some physical and biochemical properties of porcine muscle. J. Animal Sci. 26:311.

Trautman, et al., 1963. Unpublished information. From E. J. Briskey. 1963. Influence of ante- and postmortem handiing practices on properties of muscle which are related to tenderness. Proc. Meat Tenderness Symp. Campbell Soup Co.

Vogt, M. 1960. The control of the secretion of corticosteroids. The Biosynthesis and Secretion of Adrenocortical Steroids, ed. F. Clark and J. K. Grant. University Press, Cambridge.

Von Korff, R. W., and R. M. Twedt. 1957. Interaction of glycolytic and mitochondrial enzyme systems. I. Oxidation of lactate and phosphoenolpyruvate. Biochim. et Biophys. Acta 23:143.

Weber, G., R. L. Singhal, N. B. Stamm and S. K. Srivastava. 1965. Hormonal induction and suppression of liver enzyme biosynthesis. Fed. Proc. 24:745. 
White, A., P. Handler and E. L. Smith. 1964. Principles of Biochemistry. 3rd ed. McGraw-Hill Book Co., New York. p. 420 .

Wierbicki, E., L. E. Kunkle and F. E. Deatherage. 1957. Changes in the water-holding capacity and cationic shifts during the heating and freezing and thawing of the meat as revealed by a sample centrifugal method for measuring shrinkage. Food Tech. 11:67.

Wismer-Pedersen, J. 1959. Quality of pork in relation to rate of $\mathrm{pH}$ change post mortem. Food Res. 24:711.

Wismer-Pedersen, J. and E. J. Briskey. 1961. Relationship of post mortem acidity and temperature. Food Tech. $15: 232$.

Woodbury, D. M. and A. Koch. 1957. Effects of aldosterone and deoxycorticosterone on tissue electrolytes.

Proc. Soc. Exp. Biol. Med. 94:720. 
APPENDIX 
TABLE 1. SUBJECTIVE AND OBJECTIVE QUALITY EVALUATIONS FOR INDIVIDUAL ANIMALS FOR TRIAL 1

\begin{tabular}{clccc}
\hline $\begin{array}{c}\text { Animal } \\
\text { No. }\end{array}$ & Treatment & $\begin{array}{c}\text { Wisconsin } \\
\text { Quality Score }\end{array}$ & $\begin{array}{c}\text { Water } \\
\text { Binding }\end{array}$ & $\begin{array}{c}\text { Protein } \\
\text { Turbidity }\end{array}$ \\
\hline $8-1$ & Control & 3 & 32.05 & 62.8 \\
$2-1$ & Control & 2 & 34.59 & 78.3 \\
$2-11$ & Control & 3 & 24.12 & 25.0 \\
$2-5$ & Aldosterone & 1 & 32.16 & 100.0 \\
$6-0$ & Aldosterone & 2 & 30.27 & 37.0 \\
$8-8$ & Aldosterone & 1.5 & 30.47 & 94.5 \\
$2-2$ & Control & 3 & 41.35 & 2.0 \\
$9-1$ & Control & 3 & 38.34 & 3.0 \\
7.4 & Control & 3 & 36.76 & 4.5 \\
$7-8$ & Aldosterone & 2 & 45.10 & 7.5 \\
$7-3$ & Aldosterone & 2 & 42.70 & 2.3 \\
$7-7$ & Aldosterone & 2 & 42.96 & 2.5 \\
\hline
\end{tabular}

Wisconsin Pork Quality Standards: $1=$ PSE, $3=$ normal.

${ }^{b}$ Expressed as percent moisture loss.

${ }^{\mathrm{c}}$ Expressed as percent transmission. 
TABLE 2. SUBJECTIVE AND OBJECTIVE QUALITY EVALUATIONS FOR INDIVIDUAL ANIMALS FOR TRIAL 2

\begin{tabular}{rlccc}
\hline \hline $\begin{array}{c}\text { Animal } \\
\text { No. }\end{array}$ & Treatment & $\begin{array}{c}\text { Wisconsin } \\
\text { Quality Score }\end{array}$ & $\begin{array}{c}\text { Water } \\
\text { Bindina }\end{array}$ & $\begin{array}{c}\text { Protein } \\
\text { Turbidity }\end{array}$ \\
\hline $10-4$ & Control & 2 & 36.98 & 92.5 \\
$11-5$ & Control & 3 & 38.11 & 59.0 \\
$9-4$ & Control & 2 & 45.90 & 99.0 \\
$9-3$ & Aldactone & 3 & 36.64 & 48.0 \\
$14-5$ & Aldactone & 2 & 45.00 & 94.0 \\
$9-5$ & Aldactone & 3 & 36.33 & 32.5 \\
$7-6$ & Control & 3 & 45.63 & 86.5 \\
$14-4$ & Control & 1 & 50.20 & 99.0 \\
$7-11$ & Aldactone & 1 & 46.93 & 91.0 \\
$7-1$ & Aldactone & 1.5 & 46.13 & 91.5 \\
\hline
\end{tabular}

${ }^{a}$ Wisconsin Pork Quality Standards: $1=$ PSE, $3=$ normal.

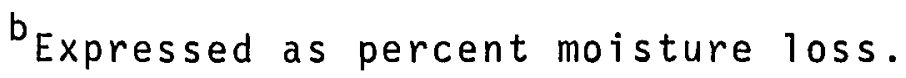

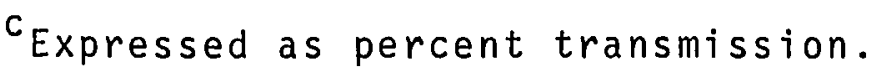


TABLE 3. SUBJECTIVE AND OBJECTIVE QUALITY EVALUATIONS FOR INDIVIDUAL ANIMALS FOR TRIAL 3

\begin{tabular}{clccc}
\hline $\begin{array}{c}\text { Animal } \\
\text { No. }\end{array}$ & Treatment & $\begin{array}{c}\text { Wisconsin } \\
\text { Quality Score }\end{array}$ & $\begin{array}{c}\text { Water } \\
\text { Binding }\end{array}$ & $\begin{array}{c}\text { Protein } \\
\text { Turbidity }\end{array}$ \\
\hline $1-4$ & Control & 1 & 47.89 & 98.0 \\
$7-7$ & Control & 1 & 45.64 & 92.3 \\
$1-5$ & Control & 1 & 43.49 & 89.0 \\
$3-6$ & Aldactazide & 3 & 38.93 & 42.5 \\
$3-4$ & Aldactazide & 3 & 45.36 & 60.5 \\
$2-3$ & Aldactazide & 2 & 43.89 & 91.5 \\
$3-7$ & Control & 1 & 39.99 & 95.0 \\
$1-4 a$ & Control & 2 & 46.89 & 93.0 \\
$1-6$ & Control & 1 & 39.45 & 95.3 \\
$1-3$ & Aldactazide & 1.5 & 41.64 & 92.0 \\
$15-1$ & Aldactazide & 3 & 44.00 & 81.5 \\
$14-13$ & Aldactazide & 2.5 & 45.07 & 55.0 \\
\hline
\end{tabular}

${ }^{a}$ Wisconsin Pork Quality Standards: $1=$ PSE, $3=$ normal.

${ }^{b}$ Expressed as percent moisture loss.

${ }^{c}$ Expressed as percent transmission. 
TABLE 4. SERUM AND MUSCLE SODIUM AND POTASSIUM FOR INDIVIDUAL ANIMALS FOR TRIAL 1

\begin{tabular}{|c|c|c|c|c|c|}
\hline \multirow{2}{*}{$\begin{array}{c}\text { Animal } \\
\text { No. }\end{array}$} & \multirow{2}{*}{ Treatment } & \multicolumn{2}{|c|}{ Serum ${ }^{\mathrm{a}}$} & \multicolumn{2}{|c|}{ iluscle $e^{b}$} \\
\hline & & $\mathrm{Na}^{+}$ & $k^{+}$ & $\mathrm{Na}^{+}$ & $k^{+}$ \\
\hline $8-1$ & Control & 155 & 4.50 & 404.62 & $3,996.56$ \\
\hline $2-1$ & Control & 154 & 5.50 & 423.68 & $4,084.38$ \\
\hline $2-11$ & Control & 155 & 4.90 & 414.40 & $4,365.48$ \\
\hline $2-5$ & Aldosterone & 157 & 5.20 & 484.46 & $4,335.35$ \\
\hline $6-0$ & Aldosterone & 159 & 4.60 & 423.42 & $4,069.77$ \\
\hline $8-8$ & Aldosterone & 151 & 5.40 & 398.64 & $3,809.92$ \\
\hline $2-2$ & Control & 158 & 6.70 & 437.74 & $4,484.76$ \\
\hline $9-1$ & Control & 159 & 6.70 & 394.65 & $4,484.57$ \\
\hline $7-4$ & Control & 166 & 7.00 & 524.83 & $4,611.09$ \\
\hline $7-8$ & Aldosterone & 162 & 6.80 & 472.42 & $4,591.73$ \\
\hline $7-3$ & Aldosterone & 155 & 5.40 & 473.72 & $4,240.96$ \\
\hline $7-7$ & Aldosterone & 154 & 6.20 & 477.98 & $4,544.84$ \\
\hline
\end{tabular}

axpressed as meq./1.

${ }^{b}$ Expressed as ppm. 
TABLE 5. SERUM AND MUSCLE SODIUM AND POTASSIUM FOR INDIVIDUAL ANIMALS FOR TRIAL 2

\begin{tabular}{|c|c|c|c|c|c|}
\hline \multirow{2}{*}{$\begin{array}{c}\text { Animal } \\
\text { No. }\end{array}$} & \multirow{2}{*}{ Treatment } & \multicolumn{2}{|c|}{ Seruma } & \multicolumn{2}{|c|}{ Muscle $e^{b}$} \\
\hline & & $\mathrm{Na}^{+}$ & $k^{+}$ & $\mathrm{Na}^{+}$ & $k^{+}$ \\
\hline $10-4$ & Control & 165 & 7.25 & 467.70 & $4,140.41$ \\
\hline $11-5$ & Control & 160 & 6.90 & 529.58 & $3,887.44$ \\
\hline $9-4$ & Control & 170 & 8.00 & 460.61 & $3,913.74$ \\
\hline $9-3$ & A)dactone & 172 & 7.10 & 573.60 & $3,843.71$ \\
\hline $14-5^{c}$ & Aldactone & 172 & 10.20 & 452.35 & $4,118.86$ \\
\hline $9-5$ & Aldactone & 158 & 5.85 & 472.49 & $4,152.89$ \\
\hline $7-6$ & Control & 158 & 7.25 & 478.35 & $4,135.96$ \\
\hline $14-4^{c}$ & Control & 168 & 12.70 & 505.60 & $4,383.39$ \\
\hline $7-11$ & Aldactone & 166 & 8.40 & 473.56 & $4,209.31$ \\
\hline $7-1$ & Aldactone & 175 & 8.65 & 417.97 & $4,475.72$ \\
\hline & $\begin{array}{l}\text { rissed as } \\
\text { ressed as } \\
\text { ck before } \\
\text { mal was dy }\end{array}$ & & $30 \mathrm{~m}$ & ress & \\
\hline
\end{tabular}


TABLE 6. SERUM AND MUSCLE SODIUM AND POTASSIUM FOR INDIVIDUAL ANIMALS FOR TRIAL 3

\begin{tabular}{|c|c|c|c|c|c|}
\hline \multirow{2}{*}{$\begin{array}{c}\text { Animal } \\
\text { No. }\end{array}$} & \multirow{2}{*}{ Treatment } & \multicolumn{2}{|c|}{ Seruma } & \multicolumn{2}{|c|}{ inuscle $e^{b}$} \\
\hline & & $\mathrm{Na}^{+}$ & $\mathrm{K}^{+}$ & $\mathrm{Na}^{+}$ & $\mathrm{k}^{+}$ \\
\hline $7-4^{c}$ & Control & 164 & 9.85 & 402.40 & $4,051.69$ \\
\hline $7-7^{c}$ & Control & 161 & 8.30 & 440.59 & $4,072.59$ \\
\hline $1-5$ & Control & 166 & 5.52 & 428.35 & $3,792.91$ \\
\hline $3-6$ & Aldactazide & 158 & 8.35 & 476.52 & $4,252.79$ \\
\hline $3-4$ & Aldactazide & 166 & 10.00 & 423.00 & $3,878.61$ \\
\hline $2-3$ & Aldactazide & 149 & 5.70 & 458.86 & $4,083.89$ \\
\hline $3-7$ & Control & 172 & 7.60 & 377.95 & $3,824.05$ \\
\hline $1-4 a^{c}$ & Control & 132 & 10.00 & 421.58 & $4,038.08$ \\
\hline $1-6$ & Control & 164 & 6.70 & 418.16 & $4,030.20$ \\
\hline $1-3$ & Aldactazide & 175 & 6.85 & 412.11 & $4,209.75$ \\
\hline $15-1$ & Aldactazide & 172 & 7.35 & 498.18 & $3,527.14$ \\
\hline $14-13$ & Aldactazide & 166 & 4.15 & 441.63 & $3,716.81$ \\
\hline
\end{tabular}

axpressed as meq./1.

${ }^{b}$ Expressed as ppm.

${ }^{c}$ Stuck before the end of 30 min. stress period because animal was dying. 
TABLE 7. TEMPERATURES AND PH VALUES OF INDIVIDUAL ANIMALS AT VARIOUS INTERVALS POST-MORTEM FOR TRIAL 1

\begin{tabular}{|c|c|c|c|c|c|c|c|c|c|c|c|c|c|c|c|}
\hline \multirow{2}{*}{$\begin{array}{c}\text { Animal } \\
\text { No. }\end{array}$} & \multirow{2}{*}{ Treatment } & \multirow{2}{*}{ I tema } & \multicolumn{13}{|c|}{ Intervals Post-Mortemb } \\
\hline & & & 0 & 0.25 & 0.50 & 0.75 & 1 & 1.5 & 2 & 2.5 & 3 & 4 & 5 & 6 & 24 \\
\hline $8-1$ & Control & $\begin{array}{l}\text { Ham } \\
\text { Loin } \\
\text { pH }\end{array}$ & $\begin{array}{c}39.0 \\
40.0 \\
6.40\end{array}$ & $\begin{array}{c}39.0 \\
40.0 \\
6.00\end{array}$ & $\begin{array}{c}39.0 \\
39.5 \\
5.95\end{array}$ & $\begin{array}{c}39.0 \\
38.0 \\
5.80\end{array}$ & $\begin{array}{c}38.5 \\
36.0 \\
5.75\end{array}$ & $\begin{array}{c}37.5 \\
35.5 \\
5.70\end{array}$ & $\begin{array}{c}33.9 \\
30.4 \\
5.80\end{array}$ & $\begin{array}{c}32.0 \\
28.0 \\
5.80\end{array}$ & $\begin{array}{c}30.0 \\
26.0 \\
5.80\end{array}$ & $\begin{array}{c}27.0 \\
23.0 \\
5.70\end{array}$ & $\begin{array}{c}24.0 \\
20.0 \\
5.75\end{array}$ & $\begin{array}{c}22.0 \\
18.0 \\
5.75\end{array}$ & $\begin{array}{l}9.0 \\
8.0 \\
5.95\end{array}$ \\
\hline $2-1$ & Control & $\begin{array}{l}\text { Ham } \\
\text { Lo in } \\
\text { pH }\end{array}$ & $\begin{array}{c}41.0 \\
41.0 \\
6.05\end{array}$ & $\begin{array}{c}41.0 \\
40.0 \\
5.90\end{array}$ & $\begin{array}{c}41.0 \\
39.5 \\
5.90\end{array}$ & $\begin{array}{c}40.0 \\
37.0 \\
5.80\end{array}$ & $\begin{array}{c}39.0 \\
35.5 \\
5.75\end{array}$ & $\begin{array}{c}38.0 \\
33.5 \\
5.80\end{array}$ & $\begin{array}{c}34.0 \\
28.0 \\
5.80\end{array}$ & $\begin{array}{c}32.0 \\
26.0 \\
5.75\end{array}$ & $\begin{array}{c}30.0 \\
24.0 \\
5.80\end{array}$ & $\begin{array}{c}27.0 \\
21.0 \\
5.80\end{array}$ & $\begin{array}{c}24.0 \\
18.5 \\
5.90\end{array}$ & $\begin{array}{c}22.0 \\
17.0 \\
5.75\end{array}$ & $\begin{array}{l}8.5 \\
7.5 \\
5.90\end{array}$ \\
\hline $2-11$ & Control & $\begin{array}{l}\text { Ham } \\
\text { Loin } \\
\text { pH }\end{array}$ & $\begin{array}{c}39.0 \\
37.0 \\
6.60\end{array}$ & $\begin{array}{c}39.0 \\
36.0 \\
6.55\end{array}$ & $\begin{array}{c}40.0 \\
36.0 \\
6.40\end{array}$ & $\begin{array}{c}39.0 \\
33.0 \\
6.20\end{array}$ & $\begin{array}{r}37.2 \\
30.6 \\
6.05\end{array}$ & $\begin{array}{c}36.3 \\
28.0 \\
5.65\end{array}$ & $\begin{array}{c}33.6 \\
25.8 \\
5.75\end{array}$ & $\begin{array}{c}31.5 \\
23.0 \\
5.70\end{array}$ & $\begin{array}{c}30.0 \\
22.0 \\
5.65\end{array}$ & $\begin{array}{c}26.0 \\
19.0 \\
5.75\end{array}$ & $\begin{array}{l}22.0 \\
17.0 \\
5.65\end{array}$ & $\begin{array}{c}20.5 \\
16.0 \\
5.60\end{array}$ & $\begin{array}{l}9.0 \\
7.4 \\
5.95\end{array}$ \\
\hline $2-5$ & $\begin{array}{l}\text { Aldos- } \\
\text { terone }\end{array}$ & $\begin{array}{l}\text { Ham } \\
\text { Lo in } \\
\text { pH }\end{array}$ & $\begin{array}{c}41.0 \\
40.0 \\
5.85\end{array}$ & $\begin{array}{c}41.0 \\
39.5 \\
5.85\end{array}$ & $\begin{array}{c}41.0 \\
38.0 \\
5.75\end{array}$ & $\begin{array}{c}40.5 \\
36.0 \\
5.70\end{array}$ & $\begin{array}{c}40.0 \\
34.0 \\
5.50\end{array}$ & $\begin{array}{c}39.0 \\
30.0 \\
5.45\end{array}$ & $\begin{array}{c}35.5 \\
25.6 \\
5.55\end{array}$ & $\begin{array}{c}34.0 \\
24.0 \\
5.65\end{array}$ & $\begin{array}{c}31.0 \\
26.0 \\
5.80\end{array}$ & $\begin{array}{c}28.0 \\
19.0 \\
5.80\end{array}$ & $\begin{array}{c}25.0 \\
16.5 \\
5.80\end{array}$ & $\begin{array}{c}22.0 \\
15.0 \\
5.85\end{array}$ & $\begin{array}{l}7.5 \\
6.8 \\
6.00\end{array}$ \\
\hline $6-0$ & $\begin{array}{l}\text { Aldos- } \\
\text { terone }\end{array}$ & $\begin{array}{l}\text { Ham } \\
\text { Lo in } \\
\text { pH }\end{array}$ & $\begin{array}{r}41.0 \\
40.0 \\
6.65\end{array}$ & $\begin{array}{c}40.5 \\
40.0 \\
6.50\end{array}$ & $\begin{array}{c}41.0 \\
39.0 \\
6.30\end{array}$ & $\begin{array}{c}41.0 \\
38.0 \\
6.10\end{array}$ & $\begin{array}{c}40.0 \\
35.0 \\
5.95\end{array}$ & $\begin{array}{c}39.0 \\
32.5 \\
5.90\end{array}$ & $\begin{array}{c}36.0 \\
27.8 \\
5.80\end{array}$ & $\begin{array}{c}34.5 \\
26.0 \\
5.85\end{array}$ & $\begin{array}{c}32.0 \\
23.9 \\
5.90\end{array}$ & $\begin{array}{c}28.5 \\
20.5 \\
5.85\end{array}$ & $\begin{array}{c}25.0 \\
18.0 \\
5.90\end{array}$ & $\begin{array}{c}22.5 \\
17.0 \\
5.85\end{array}$ & $\begin{array}{l}7.8 \\
7.0 \\
6.00\end{array}$ \\
\hline $8-8$ & $\begin{array}{l}\text { Aldos- } \\
\text { terone }\end{array}$ & $\begin{array}{l}\text { Ham } \\
\text { Lo in } \\
\text { pH }\end{array}$ & $\begin{array}{c}41.0 \\
41.0 \\
5.80\end{array}$ & $\begin{array}{c}42.0 \\
40.0 \\
5.80\end{array}$ & $\begin{array}{c}42.0 \\
39.0 \\
5.70\end{array}$ & $\begin{array}{c}41.0 \\
36.0 \\
5.80\end{array}$ & $\begin{array}{c}50.0 \\
33.6 \\
5.75\end{array}$ & $\begin{array}{c}37.4 \\
30.0 \\
5.75\end{array}$ & $\begin{array}{c}36.0 \\
28.0 \\
5.70\end{array}$ & $\begin{array}{c}33.5 \\
26.0 \\
5.70\end{array}$ & $\begin{array}{c}32.0 \\
25.0 \\
5.70\end{array}$ & $\begin{array}{c}28.4 \\
22.0 \\
5.80\end{array}$ & $\begin{array}{c}26.0 \\
20.2 \\
5.70\end{array}$ & $\begin{array}{c}24.0 \\
18.6 \\
5.70\end{array}$ & $\begin{array}{c}11.5 \\
10.0 \\
6.10\end{array}$ \\
\hline $2-2$ & Control & $\begin{array}{l}\text { Ham } \\
\text { Loin } \\
\text { pH }\end{array}$ & $\begin{array}{c}40.0 \\
39.1 \\
6.35\end{array}$ & $\begin{array}{c}39.9 \\
38.0 \\
6.50\end{array}$ & $\begin{array}{c}40.0 \\
37.0 \\
6.35\end{array}$ & $\begin{array}{c}39.5 \\
35.0 \\
6.30\end{array}$ & $\begin{array}{c}39.0 \\
33.0 \\
5.85\end{array}$ & $\begin{array}{c}37.0 \\
29.0 \\
6.00\end{array}$ & $\begin{array}{c}35.5 \\
26.0 \\
6.00\end{array}$ & $\begin{array}{c}33.5 \\
23.0 \\
5.70\end{array}$ & $\begin{array}{c}31.0 \\
20.5 \\
5.80\end{array}$ & $\begin{array}{c}27.5 \\
17.0 \\
5.80\end{array}$ & $\begin{array}{c}24.0 \\
14.4 \\
5.89\end{array}$ & $\begin{array}{c}21.0 \\
13.0 \\
5.55\end{array}$ & $\begin{array}{l}5.9 \\
4.0 \\
5.60\end{array}$ \\
\hline
\end{tabular}


TABLE 7 (cont'd.) TEMPERATURES AND $\mathrm{pH}$ VALUES OF INDIVIDUAL ANIMALS AT VARIOUS INTERVALS POST-MORTEM FOR TRIAL 1

\begin{tabular}{|c|c|c|c|c|c|c|c|c|c|c|c|c|c|c|c|}
\hline \multirow{2}{*}{$\begin{array}{c}\text { Animal } \\
\text { No. }\end{array}$} & \multirow[t]{2}{*}{ Treatment } & \multirow[t]{2}{*}{ Itema } & \multicolumn{13}{|c|}{ Intervals Post-Mortemb } \\
\hline & & & 0 & 0.25 & 0.50 & 0.75 & 1 & 1.5 & 2 & 2.5 & 3 & 4 & 5 & 6 & 24 \\
\hline $9-1$ & Control & $\begin{array}{l}\text { Ham } \\
\text { Loin } \\
\text { pH }\end{array}$ & $\begin{array}{c}39.1 \\
38.0 \\
6.10\end{array}$ & $\begin{array}{c}40.0 \\
35.4 \\
5.90\end{array}$ & $\begin{array}{c}40.0 \\
34.0 \\
5.70\end{array}$ & $\begin{array}{c}40.0 \\
33.0 \\
5.70\end{array}$ & $\begin{array}{c}40.0 \\
31.0 \\
5.80\end{array}$ & $\begin{array}{c}39.0 \\
27.5 \\
5.60\end{array}$ & $\begin{array}{r}37.0 \\
24.0 \\
5.45\end{array}$ & $\begin{array}{c}35.0 \\
21.0 \\
5.30\end{array}$ & $\begin{array}{l}33.0 \\
19.0 \\
5.45\end{array}$ & $\begin{array}{c}29.0 \\
15.0 \\
5.40\end{array}$ & $\begin{array}{c}20.1 \\
13.0 \\
5.20\end{array}$ & $\begin{array}{c}22.5 \\
12.0 \\
5.20\end{array}$ & $\begin{array}{l}6.0 \\
4.0 \\
5.45\end{array}$ \\
\hline $7-4$ & Control & $\begin{array}{l}\text { Ham } \\
\text { Lo in } \\
\text { pH }\end{array}$ & $\begin{array}{c}42.5 \\
41.5 \\
6.10\end{array}$ & $\begin{array}{c}42.9 \\
41.0 \\
5.95\end{array}$ & $\begin{array}{c}42.8 \\
39.5 \\
5.80\end{array}$ & $\begin{array}{c}42.0 \\
37.5 \\
5.60\end{array}$ & $\begin{array}{c}41.9 \\
36.8 \\
5.50\end{array}$ & $\begin{array}{c}40.0 \\
32.4 \\
5.50\end{array}$ & $\begin{array}{c}38.0 \\
29.0 \\
5.45\end{array}$ & $\begin{array}{c}36.5 \\
26.5 \\
5.50\end{array}$ & $\begin{array}{c}34.5 \\
24.0 \\
5.50\end{array}$ & $\begin{array}{c}31.0 \\
21.0 \\
5.45\end{array}$ & $\begin{array}{c}28.0 \\
19.0 \\
5.50\end{array}$ & $\begin{array}{c}25.5 \\
17.5 \\
5.50\end{array}$ & $\begin{array}{l}7.0 \\
4.0 \\
5.50\end{array}$ \\
\hline $7-8$ & $\begin{array}{l}\text { Aldos- } \\
\text { terone }\end{array}$ & $\begin{array}{l}\text { Ham } \\
\text { Lo in } \\
\text { pH }\end{array}$ & $\begin{array}{c}39.0 \\
38.9 \\
6.00\end{array}$ & $\begin{array}{c}39.0 \\
38.8 \\
5.75\end{array}$ & $\begin{array}{c}38.0 \\
38.0 \\
5.65\end{array}$ & $\begin{array}{c}36.9 \\
36.0 \\
5.40\end{array}$ & $\begin{array}{c}38.0 \\
35.0 \\
5.35\end{array}$ & $\begin{array}{c}38.0 \\
30.0 \\
5.40\end{array}$ & $\begin{array}{c}36.5 \\
27.0 \\
5.40\end{array}$ & $\begin{array}{r}34.5 \\
23.5 \\
5.40\end{array}$ & $\begin{array}{c}32.0 \\
20.0 \\
5.30\end{array}$ & $\begin{array}{c}28.0 \\
16.5 \\
5.40\end{array}$ & $\begin{array}{c}24.5 \\
13.8 \\
5.40\end{array}$ & $\begin{array}{c}20.0 \\
12.0 \\
5.40\end{array}$ & $\begin{array}{l}5.9 \\
4.0 \\
5.50\end{array}$ \\
\hline $7-3$ & $\begin{array}{l}\text { Aldos- } \\
\text { terone }\end{array}$ & $\begin{array}{l}\text { Ham } \\
\text { Loin } \\
\text { pH }\end{array}$ & $\begin{array}{c}39.9 \\
38.7 \\
6.20\end{array}$ & $\begin{array}{c}40.0 \\
39.0 \\
6.00\end{array}$ & $\begin{array}{c}40.0 \\
37.0 \\
5.70\end{array}$ & $\begin{array}{c}40.0 \\
34.0 \\
5.50\end{array}$ & $\begin{array}{c}39.5 \\
32.5 \\
5.50\end{array}$ & $\begin{array}{c}37.9 \\
28.7 \\
5.45\end{array}$ & $\begin{array}{c}36.5 \\
26.0 \\
5.40\end{array}$ & $\begin{array}{c}34.0 \\
22.0 \\
5.40\end{array}$ & $\begin{array}{c}32.2 \\
20.0 \\
5.40\end{array}$ & $\begin{array}{c}28.5 \\
15.8 \\
5.15\end{array}$ & $\begin{array}{c}25.0 \\
13.0 \\
5.28\end{array}$ & $\begin{array}{c}22.0 \\
11.5 \\
5.28\end{array}$ & $\begin{array}{l}6.0 \\
3.0 \\
5.50\end{array}$ \\
\hline $7-7$ & $\begin{array}{l}\text { Aldos- } \\
\text { terone }\end{array}$ & $\begin{array}{l}\text { Ham } \\
\text { Loin } \\
\text { pH }\end{array}$ & $\begin{array}{c}40.0 \\
39.0 \\
6.30\end{array}$ & $\begin{array}{c}40.0 \\
37.0 \\
6.20\end{array}$ & $\begin{array}{c}39.8 \\
35.0 \\
6.35\end{array}$ & $\begin{array}{r}39.2 \\
33.0 \\
6.15\end{array}$ & $\begin{array}{c}38.2 \\
30.5 \\
6.15\end{array}$ & $\begin{array}{c}57.0 \\
28.0 \\
5.90\end{array}$ & $\begin{array}{c}35.0 \\
24.0 \\
6.00\end{array}$ & $\begin{array}{c}33.0 \\
21.5 \\
5.95\end{array}$ & $\begin{array}{c}30.0 \\
18.8 \\
5.85\end{array}$ & $\begin{array}{c}26.7 \\
15.5 \\
5.60\end{array}$ & $\begin{array}{c}23.0 \\
13.0 \\
5.30\end{array}$ & $\begin{array}{l}20.0 \\
12.0 \\
5.45\end{array}$ & $\begin{array}{l}6.0 \\
4.0 \\
5.45\end{array}$ \\
\hline
\end{tabular}

${ }^{a}$ Ham and loin values are temperature, expressed as ${ }^{\circ} \mathrm{C}$. $\mathrm{pH}$ values are from the 10 in.

bexpressed in hrs. after the carcass entered the cooler. 
TABLE 8. TEMPERATURES AND PH VALUES OF INDIVIDUAL ANIMALS AT VARIOUS INTERVALS POST-MORTEM FOR TRIAL 2

\begin{tabular}{|c|c|c|c|c|c|c|c|c|c|c|c|c|c|c|c|}
\hline \multirow{2}{*}{$\begin{array}{c}\text { Anima } 1 \\
\text { No. }\end{array}$} & \multirow{2}{*}{ Treatment } & \multirow{2}{*}{ Itema } & \multicolumn{13}{|c|}{ Intervals Post-Mortemb } \\
\hline & & & 0 & 0.25 & 0.50 & 0.75 & 1 & 1.5 & 2 & 2.5 & 3 & 4 & 5 & 6 & 24 \\
\hline $10-4$ & Control & $\begin{array}{l}\text { Ham } \\
\text { Loin } \\
\text { pH }\end{array}$ & $\begin{array}{c}43.8 \\
42.8 \\
5.55\end{array}$ & $\begin{array}{c}43.2 \\
40.0 \\
5.55\end{array}$ & $\begin{array}{c}43.5 \\
36.5 \\
5.45\end{array}$ & $\begin{array}{c}52.5 \\
34.2 \\
5.35\end{array}$ & $\begin{array}{c}42.0 \\
33.0 \\
5.35\end{array}$ & $\begin{array}{l}40.0 \\
28.0 \\
5.35\end{array}$ & $\begin{array}{c}38.0 \\
25.0 \\
5.35\end{array}$ & $\begin{array}{c}35.0 \\
21.1 \\
5.35\end{array}$ & $\begin{array}{c}33.0 \\
19.0 \\
5.35\end{array}$ & $\begin{array}{c}29.0 \\
16.0 \\
5.35\end{array}$ & $\begin{array}{c}26.0 \\
14.0 \\
5.40\end{array}$ & $\begin{array}{c}22.5 \\
12.0 \\
5.35\end{array}$ & $\begin{array}{l}6.5 \\
4.5 \\
5.25\end{array}$ \\
\hline $11-5$ & Control & $\begin{array}{l}\text { Ham } \\
\text { Lo in } \\
\text { pH }\end{array}$ & $\begin{array}{c}45.0 \\
43.0 \\
5.95\end{array}$ & $\begin{array}{c}45.0 \\
43.5 \\
5.45\end{array}$ & $\begin{array}{c}45.0 \\
42.8 \\
5.50\end{array}$ & $\begin{array}{c}45.0 \\
40.0 \\
5.45\end{array}$ & $\begin{array}{c}44.5 \\
38.0 \\
5.50\end{array}$ & $\begin{array}{c}43.0 \\
34.0 \\
5.50\end{array}$ & $\begin{array}{c}41.0 \\
30.0 \\
5.60\end{array}$ & $\begin{array}{c}39.0 \\
27.0 \\
5.60\end{array}$ & $\begin{array}{c}36.8 \\
24.0 \\
5.50\end{array}$ & $\begin{array}{c}32.2 \\
20.0 \\
5.50\end{array}$ & $\begin{array}{c}39.0 \\
17.5 \\
5.50\end{array}$ & $\begin{array}{c}25.0 \\
15.5 \\
5.45\end{array}$ & $\begin{array}{l}7.0 \\
5.0 \\
5.35\end{array}$ \\
\hline $9-4$ & Control & $\begin{array}{l}\text { Ham } \\
\text { Loin } \\
\text { pH }\end{array}$ & $\begin{array}{c}45.0 \\
42.0 \\
5.30\end{array}$ & $\begin{array}{c}45.0 \\
41.0 \\
5.18\end{array}$ & $\begin{array}{c}45.0 \\
39.9 \\
5.20\end{array}$ & $\begin{array}{c}45.0 \\
38.0 \\
5.20\end{array}$ & $\begin{array}{c}44.0 \\
35.0 \\
5.30\end{array}$ & $\begin{array}{c}42.0 \\
31.0 \\
5.30\end{array}$ & $\begin{array}{r}40.0 \\
28.0 \\
5.30\end{array}$ & $\begin{array}{c}37.2 \\
24.2 \\
5.30\end{array}$ & $\begin{array}{c}35.0 \\
21.5 \\
5.30\end{array}$ & $\begin{array}{c}30.0 \\
17.5 \\
5.30\end{array}$ & $\begin{array}{c}25.5 \\
15.0 \\
5.20\end{array}$ & $\begin{array}{c}27.5 \\
13.0 \\
5.20\end{array}$ & $\begin{array}{l}6.0 \\
4.5 \\
5.25\end{array}$ \\
\hline $9-3$ & Aldactone & $\begin{array}{l}\text { Ham } \\
\text { Lo in } \\
\text { pH }\end{array}$ & $\begin{array}{c}43.0 \\
42.0 \\
6.40\end{array}$ & $\begin{array}{c}43.0 \\
47.0 \\
6.35\end{array}$ & $\begin{array}{c}43.0 \\
38.0 \\
6.35\end{array}$ & $\begin{array}{c}43.0 \\
37.5 \\
6.10\end{array}$ & $\begin{array}{c}42.0 \\
34.0 \\
5.91\end{array}$ & $\begin{array}{c}40.0 \\
30.0 \\
5.61\end{array}$ & $\begin{array}{c}38.5 \\
26.5 \\
5.75\end{array}$ & $\begin{array}{c}36.5 \\
23.5 \\
5.65\end{array}$ & $\begin{array}{c}34.0 \\
21.0 \\
5.60\end{array}$ & $\begin{array}{l}37.0 \\
17.0 \\
5.50\end{array}$ & $\begin{array}{c}27.0 \\
15.0 \\
5.50\end{array}$ & $\begin{array}{c}24.0 \\
13.0 \\
5.50\end{array}$ & $\begin{array}{l}7.5 \\
5.0 \\
5.60\end{array}$ \\
\hline $14-5$ & Aldactone & $\begin{array}{l}\text { Ham } \\
\text { Lo in } \\
\text { pH }\end{array}$ & $\begin{array}{c}44.0 \\
42.0 \\
5.60\end{array}$ & $\begin{array}{c}44.0 \\
47.0 \\
5.20\end{array}$ & $\begin{array}{c}44.0 \\
40.0 \\
5.20\end{array}$ & $\begin{array}{c}43.9 \\
37.0 \\
5.20\end{array}$ & $\begin{array}{c}43.0 \\
34.0 \\
5.20\end{array}$ & $\begin{array}{c}42.0 \\
30.5 \\
5.25\end{array}$ & $\begin{array}{c}39.5 \\
26.2 \\
5.30\end{array}$ & $\begin{array}{c}37.5 \\
23.2 \\
5.30\end{array}$ & $\begin{array}{c}35.0 \\
20.5 \\
5.30\end{array}$ & $\begin{array}{c}31.0 \\
17.0 \\
5.40\end{array}$ & $\begin{array}{c}28.0 \\
24.0 \\
5.40\end{array}$ & $\begin{array}{c}24.0 \\
73.0 \\
5.40\end{array}$ & $\begin{array}{l}7.0 \\
4.5 \\
5.20\end{array}$ \\
\hline $9-5$ & Aldactone & $\begin{array}{l}\text { Ham } \\
\text { Loin } \\
\text { pH }\end{array}$ & $\begin{array}{c}45.5 \\
43.2 \\
6.35\end{array}$ & $\begin{array}{c}45.5 \\
43.0 \\
5.88\end{array}$ & $\begin{array}{c}45.5 \\
41.0 \\
5.89\end{array}$ & $\begin{array}{c}45.0 \\
39.0 \\
5.85\end{array}$ & $\begin{array}{c}44.8 \\
37.0 \\
5.80\end{array}$ & $\begin{array}{c}43.5 \\
34.0 \\
5.70\end{array}$ & $\begin{array}{c}41.0 \\
30.8 \\
5.65\end{array}$ & $\begin{array}{c}39.0 \\
28.0 \\
5.55\end{array}$ & $\begin{array}{c}37.0 \\
26.0 \\
5.55\end{array}$ & $\begin{array}{c}34.0 \\
23.0 \\
5.50\end{array}$ & $\begin{array}{c}29.9 \\
20.5 \\
5.50\end{array}$ & $\begin{array}{c}26.5 \\
18.5 \\
5.45\end{array}$ & $\begin{array}{c}13.5 \\
17.1 \\
5.50\end{array}$ \\
\hline $7-6$ & Control & $\begin{array}{l}\text { Ham } \\
\text { Loin } \\
\text { pH }\end{array}$ & $\begin{array}{c}45.0 \\
45.0 \\
6.20\end{array}$ & $\begin{array}{c}44.8 \\
43.5 \\
5.90\end{array}$ & $\begin{array}{c}44.0 \\
39.0 \\
5.80\end{array}$ & $\begin{array}{c}43.0 \\
35.0 \\
5.50\end{array}$ & $\begin{array}{c}42.0 \\
33.0 \\
5.41\end{array}$ & $\begin{array}{c}39.0 \\
28.5 \\
5.40\end{array}$ & $\begin{array}{c}37.0 \\
25.8 \\
5.40\end{array}$ & $\begin{array}{c}33.5 \\
22.0 \\
5.40\end{array}$ & $\begin{array}{c}31.0 \\
20.5 \\
5.45\end{array}$ & $\begin{array}{c}27.5 \\
17.0 \\
5.25\end{array}$ & $\begin{array}{c}24.5 \\
15.0 \\
5.25\end{array}$ & $\begin{array}{c}21.5 \\
13.5 \\
5.25\end{array}$ & $\begin{array}{l}6.5 \\
5.0 \\
5.00\end{array}$ \\
\hline
\end{tabular}


TABLE 8 (cont'd.). TEMPERATURES AND $\mathrm{pH}$ VALUES OF INDIVIDUAL ANIMALS AT VARIOUS INTERVALS POST-MORTEM FOR TRIAL 2

\begin{tabular}{|c|c|c|c|c|c|c|c|c|c|c|c|c|c|c|c|}
\hline \multirow{2}{*}{$\begin{array}{c}\text { Anima } 1 \\
\text { No. }\end{array}$} & \multirow{2}{*}{ Treatment } & \multirow{2}{*}{ I tema } & \multicolumn{13}{|c|}{ Intervals Post-Mortemb } \\
\hline & & & 0 & 0.25 & 0.50 & 0.75 & 1 & 1.5 & 2 & 2.5 & 3 & 4 & 5 & 6 & 24 \\
\hline $14-4$ & Control & $\begin{array}{l}\text { Ham } \\
\text { Lo in } \\
\text { pH }\end{array}$ & $\begin{array}{c}44.7 \\
43.0 \\
6.00\end{array}$ & $\begin{array}{c}44.0 \\
43.0 \\
6.00\end{array}$ & $\begin{array}{c}44.5 \\
40.5 \\
5.30\end{array}$ & $\begin{array}{c}44.0 \\
39.5 \\
5.25\end{array}$ & $\begin{array}{c}43.0 \\
37.0 \\
5.25\end{array}$ & $\begin{array}{c}42.0 \\
34.0 \\
5.25\end{array}$ & $\begin{array}{c}39.0 \\
30.5 \\
5.29\end{array}$ & $\begin{array}{c}38.0 \\
29.0 \\
5.30\end{array}$ & $\begin{array}{c}35.5 \\
26.5 \\
5.30\end{array}$ & $\begin{array}{c}31.0 \\
22.5 \\
5.30\end{array}$ & $\begin{array}{c}27.0 \\
20.0 \\
5.30\end{array}$ & $\begin{array}{c}24.0 \\
17.0 \\
5.30\end{array}$ & $\begin{array}{l}7.0 \\
6.0 \\
4.90\end{array}$ \\
\hline $7-11$ & Aldactone & $\begin{array}{l}\text { Ham } \\
\text { Lo in } \\
\text { pH }\end{array}$ & $\begin{array}{c}45.5 \\
44.0 \\
6.01\end{array}$ & $\begin{array}{c}45.0 \\
44.0 \\
6.00\end{array}$ & $\begin{array}{c}45.0 \\
42.0 \\
5.90\end{array}$ & $\begin{array}{c}44.8 \\
39.0 \\
5.90\end{array}$ & $\begin{array}{c}44.0 \\
35.0 \\
5.50\end{array}$ & $\begin{array}{c}42.0 \\
31.5 \\
5.50\end{array}$ & $\begin{array}{c}40.0 \\
28.0 \\
5.40\end{array}$ & $\begin{array}{c}37.5 \\
25.0 \\
5.35\end{array}$ & $\begin{array}{r}36.0 \\
23.0 \\
5.35\end{array}$ & $\begin{array}{c}31.0 \\
18.5 \\
5.40\end{array}$ & $\begin{array}{c}27.2 \\
16.0 \\
5.40\end{array}$ & $\begin{array}{c}24.0 \\
14.0 \\
5.30\end{array}$ & $\begin{array}{l}7.0 \\
5.0 \\
5.00\end{array}$ \\
\hline $7-1$ & Aldactone & $\begin{array}{l}\text { Ham } \\
\text { Loin } \\
\text { pH }\end{array}$ & $\begin{array}{c}44.0 \\
38.0 \\
6.00\end{array}$ & $\begin{array}{c}44.0 \\
41.0 \\
5.30\end{array}$ & $\begin{array}{c}44.0 \\
39.0 \\
5.30\end{array}$ & $\begin{array}{c}44.0 \\
36.5 \\
5.35\end{array}$ & $\begin{array}{c}43.5 \\
34.0 \\
5.30\end{array}$ & $\begin{array}{c}42.5 \\
31.0 \\
5.30\end{array}$ & $\begin{array}{c}36.5 \\
26.0 \\
5.38\end{array}$ & $\begin{array}{l}34.5 \\
23.0 \\
5.38\end{array}$ & $\begin{array}{c}33.0 \\
27.5 \\
5.40\end{array}$ & $\begin{array}{l}30.0 \\
18.0 \\
5.40\end{array}$ & $\begin{array}{l}27.0 \\
16.0 \\
5.30\end{array}$ & $\begin{array}{c}24.0 \\
13.5 \\
5.30\end{array}$ & $\begin{array}{l}7.0 \\
5.0 \\
4.95\end{array}$ \\
\hline
\end{tabular}

¿Ham and loin values are temperature, expressed as ${ }^{\circ} \mathrm{C}$. $\mathrm{FH}$ values are from the loin.

bexpressed in hrs. after the carcass entered the cooler. 
TABLE 9. TEMPERATURES AND $\mathrm{pH}$ VALUES OF 'NDIVIDUAL ANIMALS AT VARIOUS INTERVALS POST-MORTEM - , R TRIAL 3

\begin{tabular}{|c|c|c|c|c|c|c|c|c|c|c|c|c|c|c|c|}
\hline \multirow{2}{*}{$\begin{array}{c}\text { Anima } 1 \\
\text { No. }\end{array}$} & \multirow{2}{*}{ Treatment } & \multirow{2}{*}{ Itema } & \multicolumn{13}{|c|}{ Intervals Post-Mortemb } \\
\hline & & & 0 & 0.25 & 0.50 & 0.75 & 1 & 1.5 & 2 & 2.5 & 3 & 4 & 5 & 6 & 24 \\
\hline $1-4$ & Control & $\begin{array}{l}\text { Ham } \\
\text { Loin } \\
\text { pH }\end{array}$ & $\begin{array}{c}44.0 \\
42.0 \\
5.70\end{array}$ & $\begin{array}{c}43.1 \\
41.1 \\
5.75\end{array}$ & $\begin{array}{c}42.0 \\
39.9 \\
5.75\end{array}$ & $\begin{array}{c}41.0 \\
38.2 \\
5.70\end{array}$ & $\begin{array}{c}47.0 \\
37.0 \\
5.90\end{array}$ & $\begin{array}{c}39.8 \\
32.5 \\
5.85\end{array}$ & $\begin{array}{c}38.0 \\
29.5 \\
5.85\end{array}$ & $\begin{array}{c}35.8 \\
26.2 \\
5.85\end{array}$ & $\begin{array}{c}33.5 \\
23.9 \\
5.85\end{array}$ & $\begin{array}{c}30.0 \\
20.0 \\
5.80\end{array}$ & $\begin{array}{c}25.8 \\
17.0 \\
5.65\end{array}$ & $\begin{array}{c}23.5 \\
15.0 \\
5.70\end{array}$ & $\begin{array}{l}6.0 \\
6.0 \\
5.75\end{array}$ \\
\hline $7-7$ & Control & $\begin{array}{l}\text { Ham } \\
\text { Loin } \\
\text { pH }\end{array}$ & $\begin{array}{c}44.0 \\
42.0 \\
5.90\end{array}$ & $\begin{array}{c}43.8 \\
38.0 \\
5.82\end{array}$ & $\begin{array}{c}43.8 \\
37.0 \\
5.80\end{array}$ & $\begin{array}{c}43.0 \\
33.0 \\
5.90\end{array}$ & $\begin{array}{c}43.0 \\
32.5 \\
5.85\end{array}$ & $\begin{array}{c}41.0 \\
28.2 \\
5.80\end{array}$ & $\begin{array}{c}39.0 \\
25.0 \\
5.75\end{array}$ & $\begin{array}{c}57.0 \\
22.0 \\
5.75\end{array}$ & $\begin{array}{c}35.5 \\
20.0 \\
5.65\end{array}$ & $\begin{array}{c}31.3 \\
16.0 \\
5.65\end{array}$ & $\begin{array}{c}29.0 \\
15.0 \\
5.65\end{array}$ & $\begin{array}{c}26.0 \\
13.0 \\
5.65\end{array}$ & $\begin{array}{l}9.0 \\
5.0 \\
5.70\end{array}$ \\
\hline $1-5$ & Control & $\begin{array}{l}\text { Ham } \\
\text { Loin } \\
\text { pH }\end{array}$ & $\begin{array}{c}45.0 \\
44.0 \\
6.10\end{array}$ & $\begin{array}{c}45.0 \\
44.0 \\
6.10\end{array}$ & $\begin{array}{c}45.0 \\
43.0 \\
6.10\end{array}$ & $\begin{array}{c}45.0 \\
42.5 \\
6.10\end{array}$ & $\begin{array}{c}45.0 \\
39.0 \\
6.05\end{array}$ & $\begin{array}{c}44.8 \\
36.0 \\
6.00\end{array}$ & $\begin{array}{c}43.5 \\
33.0 \\
6.00\end{array}$ & $\begin{array}{c}42.0 \\
30.5 \\
5.90\end{array}$ & $\begin{array}{c}39.0 \\
26.0 \\
5.95\end{array}$ & $\begin{array}{c}36.0 \\
23.0 \\
5.90\end{array}$ & $\begin{array}{c}32.0 \\
20.5 \\
6.00\end{array}$ & $\begin{array}{c}30.0 \\
19.5 \\
5.90\end{array}$ & $\begin{array}{c}15.5 \\
13.0 \\
5.90\end{array}$ \\
\hline $3-6$ & $\begin{array}{l}\text { Aldacta- } \\
\text { zide }\end{array}$ & $\begin{array}{l}\text { Ham } \\
\text { Lo in } \\
\text { pH }\end{array}$ & $\begin{array}{c}42.9 \\
42.0 \\
5.90\end{array}$ & $\begin{array}{c}43.0 \\
40.0 \\
5.80\end{array}$ & $\begin{array}{c}43.0 \\
37.6 \\
5.90\end{array}$ & $\begin{array}{c}42.1 \\
34.0 \\
5.85\end{array}$ & $\begin{array}{c}42.0 \\
31.0 \\
6.00\end{array}$ & $\begin{array}{c}40.0 \\
27.0 \\
5.90\end{array}$ & $\begin{array}{c}38.0 \\
23.0 \\
5.90\end{array}$ & $\begin{array}{c}36.0 \\
20.0 \\
5.90\end{array}$ & $\begin{array}{c}33.8 \\
18.0 \\
5.75\end{array}$ & $\begin{array}{c}30.0 \\
15.0 \\
5.70\end{array}$ & $\begin{array}{c}27.2 \\
13.5 \\
5.60\end{array}$ & $\begin{array}{c}23.5 \\
11.5 \\
5.60\end{array}$ & $\begin{array}{l}7.5 \\
5.8 \\
5.70\end{array}$ \\
\hline $3-4$ & $\begin{array}{l}\text { Aldacta- } \\
\text { zide }\end{array}$ & $\begin{array}{l}\text { Ham } \\
\text { Lo in } \\
\text { pH }\end{array}$ & $\begin{array}{c}43.0 \\
41.9 \\
6.20\end{array}$ & $\begin{array}{c}42.7 \\
38.0 \\
6.10\end{array}$ & $\begin{array}{c}42.5 \\
38.0 \\
6.00\end{array}$ & $\begin{array}{c}52.0 \\
35.0 \\
6.00\end{array}$ & $\begin{array}{c}41.0 \\
32.5 \\
6.00\end{array}$ & $\begin{array}{c}39.0 \\
29.0 \\
6.00\end{array}$ & $\begin{array}{c}37.0 \\
26.0 \\
5.90\end{array}$ & $\begin{array}{c}35.0 \\
23.5 \\
5.90\end{array}$ & $\begin{array}{c}33.0 \\
21.5 \\
5.85\end{array}$ & $\begin{array}{c}30.7 \\
19.0 \\
5.90\end{array}$ & $\begin{array}{c}26.0 \\
16.0 \\
5.85\end{array}$ & $\begin{array}{c}23.0 \\
14.0 \\
5.95\end{array}$ & $\begin{array}{l}8.0 \\
6.0 \\
5.95\end{array}$ \\
\hline $2-3$ & $\begin{array}{l}\text { Aldacta- } \\
\text { zide }\end{array}$ & $\begin{array}{l}\text { Ham } \\
\text { Lo in } \\
\text { pH }\end{array}$ & $\begin{array}{c}42.5 \\
42.0 \\
6.30\end{array}$ & $\begin{array}{c}43.5 \\
38.5 \\
5.75\end{array}$ & $\begin{array}{c}43.0 \\
35.0 \\
5.90\end{array}$ & $\begin{array}{c}43.0 \\
34.5 \\
5.90\end{array}$ & $\begin{array}{c}42.0 \\
30.5 \\
5.75\end{array}$ & $\begin{array}{l}50.0 \\
27.0 \\
5.60\end{array}$ & $\begin{array}{c}38.0 \\
24.0 \\
5.60\end{array}$ & $\begin{array}{c}35.8 \\
22.0 \\
5.55\end{array}$ & $\begin{array}{c}32.5 \\
19.0 \\
5.65\end{array}$ & $\begin{array}{c}30.0 \\
17.0 \\
5.60\end{array}$ & $\begin{array}{c}26.0 \\
14.5 \\
5.65\end{array}$ & $\begin{array}{c}24.0 \\
13.5 \\
5.70\end{array}$ & $\begin{array}{l}7.9 \\
5.5 \\
5.75\end{array}$ \\
\hline $3-7$ & Control & $\begin{array}{l}\text { Ham } \\
\text { Lo in } \\
\text { pHC }\end{array}$ & $\begin{array}{c}43.0 \\
40.2 \\
5.90\end{array}$ & $\begin{array}{c}43.0 \\
40.3 \\
5.90\end{array}$ & $\begin{array}{c}42.9 \\
38.0 \\
5.95\end{array}$ & $\begin{array}{c}43.0 \\
37.0 \\
5.95\end{array}$ & $\begin{array}{c}42.0 \\
34.0 \\
--\end{array}$ & $\begin{array}{c}40.0 \\
30.1 \\
--\end{array}$ & $\begin{array}{c}38.9 \\
28.2 \\
--\end{array}$ & $\begin{array}{c}37.0 \\
25.5 \\
--\end{array}$ & $\begin{array}{c}36.0 \\
24.0 \\
--\end{array}$ & $\begin{array}{c}31.0 \\
19.0 \\
5.55\end{array}$ & $\begin{array}{c}28.0 \\
16.0 \\
--\end{array}$ & $\begin{array}{c}24.0 \\
13.5 \\
--\end{array}$ & $\begin{array}{l}7.0 \\
5.0 \\
--\end{array}$ \\
\hline
\end{tabular}


TABLE 9 (cont'd.). TEMPERATURES AND $\mathrm{pH}$ VALUES OF INDIVIDUAL ANIMALS AT VARIOUS INTERVALS POST-MORTEM FOR TRIAL 3

\begin{tabular}{|c|c|c|c|c|c|c|c|c|c|c|c|c|c|c|c|}
\hline \multirow{2}{*}{$\begin{array}{c}\text { An ima } 1 \\
\text { No. }\end{array}$} & \multirow{2}{*}{ Treatment } & \multirow{2}{*}{ Item $^{\mathrm{a}}$} & \multicolumn{13}{|c|}{ Intervals Post-Mortemb } \\
\hline & & & 0 & 0.25 & 0.50 & 0.75 & 1 & 1.5 & 2 & 2.5 & 3 & 4 & 5 & 6 & 24 \\
\hline \multirow[t]{2}{*}{$1-4 a$} & Control & $\begin{array}{l}\text { Ham } \\
\text { Loin }\end{array}$ & $\begin{array}{l}44.5 \\
42.0\end{array}$ & $\begin{array}{l}45.0 \\
40.0\end{array}$ & $\begin{array}{l}43.5 \\
36.0\end{array}$ & $\begin{array}{l}42.1 \\
33.0\end{array}$ & $\begin{array}{l}42.9 \\
32.0\end{array}$ & $\begin{array}{l}41.1 \\
28.3\end{array}$ & $\begin{array}{l}39.0 \\
25.0\end{array}$ & $\begin{array}{l}36.0 \\
21.6\end{array}$ & $\begin{array}{l}34.5 \\
19.5\end{array}$ & $\begin{array}{l}29.0 \\
15.0\end{array}$ & $\begin{array}{l}25.5 \\
13.0\end{array}$ & $\begin{array}{l}24.0 \\
12.0\end{array}$ & $\begin{array}{l}7.0 \\
5.0\end{array}$ \\
\hline & & $\mathrm{pH}$ & 6.10 & -- & - & -- & - & -- & -- & -- & - & 5.55 & - & -- & -- \\
\hline \multirow[t]{2}{*}{$1-6$} & Control & $\begin{array}{l}\text { Ham } \\
\text { Loin }\end{array}$ & $\begin{array}{l}44.5 \\
43.9\end{array}$ & $\begin{array}{l}45.0 \\
43.0\end{array}$ & $\begin{array}{l}45.0 \\
42.0\end{array}$ & $\begin{array}{l}44.5 \\
39.0\end{array}$ & $\begin{array}{l}44.5 \\
37.0\end{array}$ & $\begin{array}{l}43.5 \\
33.9\end{array}$ & $\begin{array}{l}42.0 \\
31.8\end{array}$ & $\begin{array}{l}39.5 \\
28.0\end{array}$ & $\begin{array}{l}33.5 \\
26.0\end{array}$ & $\begin{array}{l}34.0 \\
22.0\end{array}$ & $\begin{array}{l}31.0 \\
20.0\end{array}$ & $\begin{array}{l}29.0 \\
18.5\end{array}$ & $\begin{array}{l}15.0 \\
13.0\end{array}$ \\
\hline & & $\mathrm{pH}$ & -- & -- & -- & -- & -- & -- & -- & -- & -- & 5.50 & -- & -- & -- \\
\hline \multirow[t]{2}{*}{$1-3$} & Aldacta- & Ham & 43.5 & 43.5 & 43.2 & 42.5 & 42.0 & 38.1 & 37.9 & 36.5 & 35.0 & 31.0 & 27.0 & 24.2 & 7.0 \\
\hline & zide & $\begin{array}{l}\text { Loin } \\
\text { pH }\end{array}$ & $\begin{array}{c}42.0 \\
5.70\end{array}$ & $\begin{array}{r}42.1 \\
5.65\end{array}$ & $\begin{array}{c}40.2 \\
5.90\end{array}$ & $\begin{array}{c}36.9 \\
5.72\end{array}$ & $\begin{array}{c}35.0 \\
5.90\end{array}$ & $\begin{array}{c}28.0 \\
--\end{array}$ & $\begin{array}{c}27.1 \\
--\end{array}$ & $\begin{array}{c}24.9 \\
--\end{array}$ & $\begin{array}{c}22.0 \\
--\end{array}$ & $\begin{array}{c}18.5 \\
5.60\end{array}$ & $\begin{array}{c}15.0 \\
--\end{array}$ & $\begin{array}{c}13.0 \\
--\end{array}$ & $\begin{array}{l}5.0 \\
--\end{array}$ \\
\hline \multirow[t]{2}{*}{$15-1$} & $\begin{array}{l}\text { Aldacta- } \\
\text { zide }\end{array}$ & $\begin{array}{l}\text { Ham } \\
\text { Lo in }\end{array}$ & $\begin{array}{l}44.0 \\
42.0\end{array}$ & $\begin{array}{l}43.8 \\
40.0\end{array}$ & $\begin{array}{l}43.2 \\
38.0\end{array}$ & $\begin{array}{l}43.1 \\
37.0\end{array}$ & $\begin{array}{l}42.9 \\
35.2\end{array}$ & $\begin{array}{l}41.7 \\
31.5\end{array}$ & $\begin{array}{l}40.0 \\
29.0\end{array}$ & $\begin{array}{l}38.0 \\
26.0\end{array}$ & $\begin{array}{l}35.5 \\
22.5\end{array}$ & $\begin{array}{l}31.5 \\
18.0\end{array}$ & $\begin{array}{l}27.5 \\
16.0\end{array}$ & $\begin{array}{l}23.0 \\
14.0\end{array}$ & $\begin{array}{l}6.9 \\
5.0\end{array}$ \\
\hline & & $\mathrm{pH}$ & -- & -- & -- & -- & -- & -- & -- & -- & -- & 5.75 & -- & -- & -- \\
\hline \multirow[t]{3}{*}{$14-13$} & Aldacta- & Ham & 44.0 & 44.5 & 44.0 & 43.2 & 42.0 & 50.0 & 38.0 & 35.0 & 32.5 & 30.0 & 26.0 & 23.0 & 8.2 \\
\hline & zide & Lo in & 42.0 & 41.2 & 38.0 & 36.0 & 32.8 & 29.9 & 26.0 & 22.0 & 20.0 & 18.0 & 15.0 & 13.0 & 5.8 \\
\hline & & $\mathrm{pH}$ & -- & -- & -- & -- & -- & -- & -- & -- & -- & 5.50 & -- & -- & -- \\
\hline
\end{tabular}

${ }^{2}$ Ham and loin values are temperature, expressed as ${ }^{\circ} \mathrm{C}$. $\mathrm{pH}$ values are from the 10 in.

bexpressed in hrs. after the carcass entered the cooler.

${ }^{c}$ Some pH values not obtained due to mechanical difficulties. 
TABLE 10. ANALYSIS OF VARIANCE FOR WISCONSIN QUALITY SCORE FOR TRIAL I

\begin{tabular}{lcc}
\hline Source & d.f. & Mean Squares \\
\hline Blocks & 1 & 0.52 \\
Periods & 2 & 0.02 \\
Treatments & 1 & $3.52 * *$ \\
$P \times T$ & 2 & 0.27 \\
Error & 5 & 0.12 \\
\hline$* \star(P<.01)$ & &
\end{tabular}

TABLE 11. ANALYSIS OF VARIANCE FOR WATER BINDING FOR TRIAL 1

\begin{tabular}{lcc}
\hline Source & d.f. & Mean Squares \\
\hline Blocks & 1 & $337.19 * *$ \\
Periods & 2 & 17.82 \\
Treatments & 1 & 22.39 \\
P $x T$ & 2 & 10.17 \\
Error & 5 & 6.54 \\
\hline$* *(P<.01)$ & &
\end{tabular}

TABLE 12. ANALYSIS OF VARIANCE FOR PROTEIN TURBIDITY FOR TRIAL I

\begin{tabular}{lcc}
\hline Source & d.f. & Mean Squares \\
\hline Blocks & 1 & $11,768.80 * *$ \\
Periods & 2 & 200.22 \\
Treatments & 1 & 387.60 \\
P X T & 2 & 824.14 \\
Error & 5 & 447.37 \\
\hline
\end{tabular}

$$
\star *(P<.01)
$$


TABLE 13. ANALYSIS OF VARIANCE FOR SERUM SODIUM FOR TRIAL 1

\begin{tabular}{lcc}
\hline Source & d.f. & Mean Squares \\
\hline Blocks & 1 & 44.08 \\
Periods & 2 & 2.58 \\
Treatments & 1 & 6.75 \\
P X T & 2 & 33.25 \\
Error & 5 & 11.68 \\
\hline
\end{tabular}

TABLE 14. ANALYSIS OF VARIANCE FOR SERUM POTASSIUM FOR TRIAL 1

\begin{tabular}{lcc}
\hline \multicolumn{1}{c}{ Source } & d.f. & Mean Squares \\
\hline Blocks & 1 & $6.31^{* *}$ \\
Periods & 2 & 0.12 \\
Treatments & 1 & 0.24 \\
P X T & 2 & 0.58 \\
Error & 5 & 0.19 \\
\hline
\end{tabular}

$* *(P<.01)$

TABLE 15. ANALYSIS OF VARIANCE FOR MUSCLE SODIUM FOR TRIAL 1

\begin{tabular}{lcc}
\hline \multicolumn{1}{c}{ Source } & d.f. & Mean Squares \\
\hline Blocks & 1 & $4,489.97$ \\
Periods & 2 & 723.73 \\
Treatments & 1 & $1,423.98$ \\
PXT & 2 & $2,193.74$ \\
Error & 5 & $1,412.44$ \\
\hline
\end{tabular}


TABLE 16. ANALYSIS OF VARIANCE FOR MUSCLE POTASSIUM FOR TRIAL 1

\begin{tabular}{lcc}
\hline \multicolumn{1}{c}{ Source } & d.f. & Mean Squares \\
\hline Blocks & 1 & $439,488.86 * *$ \\
Periods & 2 & $20,394.68$ \\
Treatments & 1 & $15,715.87$ \\
$P \times T$ & 2 & $73,645.47$ \\
Error & 5 & $21,498.20$ \\
\hline$* *(P<.01)$ & &
\end{tabular}

TABLE 17. LEAST-SQUARES ANALYSIS OF VARIANCE FOR WISCONSIN QUALITY SCORE FOR TRIAL 2

\begin{tabular}{lcc}
\hline \multicolumn{1}{c}{ Source } & d.f. & Mean Squares \\
\hline Blocks & 1 & 1.53 \\
Periods & 2 & 0.14 \\
Treatments & 1 & 0.02 \\
P X T & 2 & 0.39 \\
Error & 3 & 1.03 \\
\hline
\end{tabular}

TABLE 18. LEAST-SQUARES ANALYSIS OF VARIANCE FOR WATER BINDING FOR TRIAL 2

\begin{tabular}{lcc}
\hline \multicolumn{1}{c}{ Source } & d.f. & Mean Squares \\
\hline Blocks & 1 & $129.28^{*}$ \\
Periods & 2 & 13.48 \\
Treatments & 1 & 14.74 \\
$P \times T$ & 2 & 22.33 \\
Error & 3 & 11.60 \\
\hline$*(P<.05)$ & &
\end{tabular}


TABLE 19. LEAST-SQUARES ANALYSIS OF VARIANCE FOR PROTEIN TURBIDITY FOR TRIAL 2

\begin{tabular}{lcc}
\hline \multicolumn{1}{c}{ Source } & d.f. & Mean Squares \\
\hline Blocks & 1 & 693.78 \\
Periods & 2 & 79.40 \\
Treatments & 1 & $1,323.14$ \\
P X T & 2 & $1,088.04$ \\
Error & 3 & 350.61 \\
\hline
\end{tabular}

TABLE 20. LEAST-SQUARES ANALYSIS OF VARIANCE FOR SERUM SODIUM FOR TRIAL 2

\begin{tabular}{lcc}
\hline \multicolumn{1}{c}{ Source } & d.f. & Mean Squares \\
\hline Blocks & 1 & 0.50 \\
Periods & 2 & 19.29 \\
Treatments & 1 & 6.25 \\
P X T & 2 & 85.05 \\
Error & 3 & 26.17 \\
\hline
\end{tabular}

TABLE 21. LEAST-SQUARES ANALYSIS OF VARIANCE FOR SERUM POTASSIUM FOR TRIAL 2

\begin{tabular}{lcc}
\hline Source & d.f. & Mean Squares \\
\hline Blocks & 1 & 3.85 \\
Periods & 2 & 5.05 \\
Treatments & 1 & 1.02 \\
P X T & 2 & 1.17 \\
Error & 3 & 5.00 \\
\hline
\end{tabular}


TABLE 22. LEAST-SQUARES ANALYSIS OF VARIANCE FOR MUSCLE SODIUM FOR TRIAL 2

\begin{tabular}{lcc}
\hline Source & d.f. & Mean Squares \\
\hline Blocks & 1 & $2,728.76$ \\
Periods & 2 & $1,508.25$ \\
Treatments & 1 & 99.95 \\
PXT & 2 & $4,576.02$ \\
Error & 3 & $1,070.16$ \\
\hline
\end{tabular}

TABLE 23. LEAST-SQUARES ANALYSIS OF VARIANCE FOR MUSCLE POTASSIUM FOR TRIAL 2

\begin{tabular}{lcc}
\hline Source & d.f. & Mean Squares \\
\hline Blocks & 1 & $184,212.36$ \\
Periods & 2 & $18,807.48$ \\
Treatments & 1 & $20,930.86$ \\
P X T & 2 & $27,870.88$ \\
Error & 3 & $23,095.65$ \\
\hline
\end{tabular}

TABLE 24. ANALYSIS OF VARIANCE FOR WISCONSIN QUALITY FOR TRIAL 3

\begin{tabular}{lcc}
\hline Source & d.f. & Mean Squares \\
\hline Blocks & 1 & 0.00 \\
Periods & 2 & 0.52 \\
Treatments & 1 & $5.33^{*}$ \\
P X T & 2 & 0.02 \\
Error & 5 & 0.35 \\
\hline
\end{tabular}

$*(P<.05)$ 
TABLE 25. ANALYSIS OF VARIANCE FOR WATER BINDING FOR TRIAL 3

\begin{tabular}{lcc}
\hline \multicolumn{1}{c}{ Source } & d.f. & Mean Squares \\
\hline Blocks & 1 & 5.55 \\
Periods & 2 & 12.18 \\
Treatments & 1 & 1.66 \\
PXT & 2 & 11.64 \\
Error & 5 & 7.98 \\
\hline
\end{tabular}

TABLE 26. ANALYSIS OF VARIANCE FOR PROTEIN TURBIDITY FOR TRIAL 3

\begin{tabular}{lcc}
\hline \multicolumn{1}{c}{ Source } & d.f. & Mean Squares \\
\hline Blocks & 1 & 120.33 \\
Periods & 2 & 0.96 \\
Treatments & 1 & $1,624.01$ \\
P X T & 2 & 28.74 \\
Error & 5 & 403.20 \\
\hline
\end{tabular}

TABLE 27. ANALYSIS OF VARIANCE FOR SERUM SODIUM FOR TRIAL 3

\begin{tabular}{lcc}
\hline \multicolumn{1}{c}{ Source } & d.f. & Mean Squares \\
\hline Blocks & 1 & 24.08 \\
Periods & 2 & 92.33 \\
Treatments & 1 & 60.75 \\
P X T & 2 & 252.00 \\
Error & 5 & 147.48 \\
\hline
\end{tabular}


TABLE 28. ANALYSIS OF VARIANCE FOR SERUM POTASSIUM FOR TRIAL 3

\begin{tabular}{lcc}
\hline \multicolumn{1}{c}{ Source } & d.f. & Mean Squares \\
\hline Blocks & 1 & 2.14 \\
Periods & 2 & $12.72^{*}$ \\
Treatments & 1 & 2.58 \\
P X T & 2 & 0.16 \\
Error & 5 & 1.67 \\
\hline
\end{tabular}

$*(P<.05)$

TABLE 29. ANALYSIS OF VARIANCE FOR MUSCLE SODIUM FOR TRIAL 3

\begin{tabular}{lcc}
\hline \multicolumn{1}{c}{ Source } & d.f. & Mean Squares \\
\hline Blocks & 1 & 301.10 \\
Periods & 2 & 853.70 \\
Treatments & 1 & $4,080.03$ \\
P X T & 2 & 225.06 \\
Error & 5 & $1,055.84$ \\
\hline
\end{tabular}

TABLE 30. ANALYSIS OF VARIANCE FOR MUSCLE POTASSIUM FOR TRIAL 3

\begin{tabular}{lcc}
\hline \multicolumn{1}{c}{ Source } & d.f. & Mean Squares \\
\hline Blocks & 1 & $51,541.97$ \\
Periods & 2 & $49,893.91$ \\
Treatments & 1 & $1,645.72$ \\
P X T & 2 & $104,395.72$ \\
Error & 5 & $26,636.48$ \\
\hline
\end{tabular}


VITA

Ferdinand Ludvic Passbach, Jr., was born in Natchez, Mississippi, November 21,1941 , and received his elementary education at Cathedral Elementary School. He attended Cathedral High School, Natchez, Mississippi, and graduated in May, 1959.

In September, 1959, he enrolled at Loyola University, New Orleans, Louisiana, where he majored in biology until May, 1960. The following September, he enrolled at Mississippi State University, where he received the degree of Bachelor of Science in Agriculture in May, 1963.

From September, 1963, until August, 1965, he attended Mississippi State University as a Graduate Assistant in the Animal Husbandry Department. He was awarded the degree of Master of Science in Agriculture in August, 1965.

In September, 1965, he accepted a position as Associate in the Department of Animal Science at Louisiana State University and began working toward his doctorate. Two years later he relinquished this position for one as a Graduate Assistant so that he could more actively pursue his degree. Since that time he has been engaged in fulfilling the requirements for a Doctor of Philosophy in the Department of Animal Science with a minor in biochemistry. 
Candidate: Ferdinand Ludvic Passbech, Jr.

Major Field: Animal Science

Title of Thesis: Influence of Aldosterone on the Quality of Porcine Muscle.

Approved:

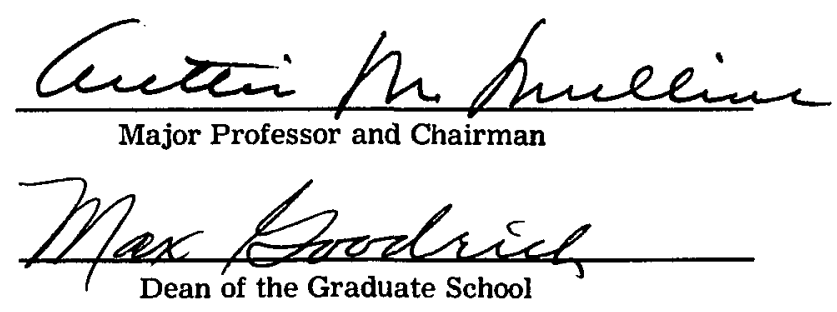

EXAMINING COMMITTEE:

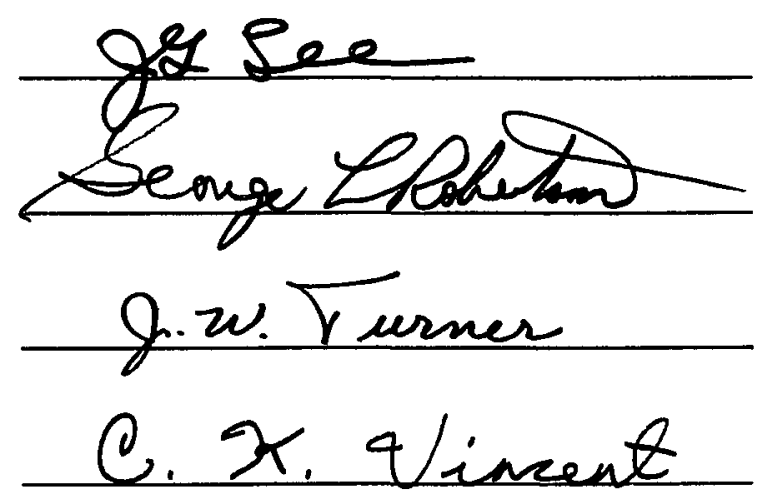

Date of Examination:

July 1, 1969 